\title{
II. Haçlı Seferinin Gerçekleştiği Dönemde Denizli ve Çevresinin Siyasi Yapısı
}

\author{
İbrahim BALIK \\ Dr. Öğr. Üyesi, Pamukkale Üniversitesi, Fen Edebiyat Fakültesi, Tarih Bölümü, \\ Denizli, Türkiye, ibalik@pau.edu.tr (Sorumlu Yazar/Corresponding Author)
}

\begin{tabular}{|c|c|}
\hline Makale Bilgileri & $\ddot{\mathbf{O Z Z}}$ \\
\hline $\begin{array}{l}\text { Makale Geçmişi } \\
\text { Geliş: } 02.11 .2020 \\
\text { Kabul: } 23.04 .2021 \\
\text { Yayın: } 31.12 .2021\end{array}$ & $\begin{array}{l}\text { Almanlar ve Fransızlar, ikinci Haçlı Seferinin liderliğini üstlendiler. } 1147 \text { yılının son yarısında yola } \\
\text { çıkan ikinci haçlı ordusu İstanbul'dan, Anadolu'ya geçirildi. Almanlar, Eskişehir yakınlarında ağır bir } \\
\text { yenilgi aldılar ve İznik'e geri döndüler. Bu yüzden arkadan gelen Fransız kuvvetleri Anadolu'yu geçmek } \\
\text { için farklı bir güzergâh belirlediler. Ancak Denizli'ye doğru ilerlemeye başladıkları andan itibaren yoğun } \\
\text { Türkmen saldırılarına maruz kaldılar. Yiyecek ihtiyaçlarını giderebilmek için Denizli yakınlarındaki }\end{array}$ \\
\hline Anahtar Kelimeler: & Laodikeia şehrini hedeflediler. Ne var ki bu şehre gelince büyük bir sürprizle karşılaştılar. Çünkü şehrin \\
\hline $\begin{array}{l}\text { II. Haçlı Seferi, } \\
\text { Laodikeia, } \\
\text { Kazıkbeli, } \\
\text { Honaz Dağ1, } \\
\text { VII. Louis. }\end{array}$ & $\begin{array}{l}\text { Rum ahalisi haçlı korkusundan şehri boşalmıştı. Laodikeia'da umduğunu bulamayan Fransa Kralı VII. } \\
\text { Louis, bir an önce Honaz Dağını aşıp, daha güvenli bölgelere ulaşmak niyetinde idi. Bunun için } 7 \text { Ocak } \\
1148 \text { tarihinde Ege Bölgesinin bu en yüksek dağını aşmaya karar verdi. Ancak bölgeyi çok iyi bilen } \\
\text { Türkmenler hazırladıkları pusu ile Haçlı ordularına büyük bir darbe vurdular. Bu yenilginin en önemli } \\
\text { sebeplerinden birisi Denizli ve çevresindeki Türkmen yoğunluğunun Haçlılar tarafından fark edilememiş } \\
\text { olmasıdır. II. Haçlı seferine katılan kuvvetler bu yolu güvenli olduğunu düşünmüşlerdi. Her ne kadar } \\
\text { bölge Bizans kontrolünde görünüyor ise de aslında Denizli ve çevresinde hâkimiyet büyük ölçüde } \\
\text { Türkmenlerin eline geçmişti. Bizans'ın egemenliği göstermelikti. Bunu fark edemeyen Haçlılar, } \\
\text { Denizli'de ağır bir yenilgi aldılar. }\end{array}$ \\
\hline
\end{tabular}

\section{Political Structure of Denizli and Its Vicinity During the Period of the Second Crusade}

\begin{tabular}{ll}
\hline Article Info & ABSTRACT \\
\hline Article History & $\begin{array}{l}\text { The Germans and French the lead of second Crusade. The Germans are near Eskişehir suffered a heavy } \\
\text { defeat and returned to Iznik. French forces started to advance towards Denizli, they were exposed }\end{array}$ \\
$\begin{array}{l}\text { Received: } 02.11 .2020 \\
\text { intensive Turkmen attacks. To meet their food needs, they aimed to visit the city of Laodikeia near }\end{array}$ \\
$\begin{array}{l}\text { Published: } 31.12 .2021 \\
\text { Denizli. However, the Greek people of this city had left Louis could not find what he had hoped in } \\
\text { Leywords: }\end{array}$ & $\begin{array}{l}\text { Laodikeia and intended to cross Honaz Mountain as soon as possible and reach safer regions. On January } \\
\text { know the region well they dealt a great blow to the Crusaders with the ambush they prepared. One of the }\end{array}$ \\
II. Crusade, & biggest reason for this defeat is Turkmen density in Denizli and around was not noticed by the Crusaders. \\
Laodikeia, & $\begin{array}{l}\text { As this way is safe was considered. Although the region seems under Byzantine control, Turkmens had } \\
\text { Kall control over Denizli and its surroundings. The sovereignty of Byzantium was for show. Crusaders }\end{array}$ \\
Honaz Montain, & who could not realize this, took a heavy defeat in Denizli. \\
VII. Louis. &
\end{tabular}

Atıf/Citation: Balık, İbrahim. "II. Haçlı Seferinin Gerçekleştiği Dönemde Denizli ve Çevresinin Siyasi Yapısı”. Selçuklu Medeniyeti Araştırmaları Dergisi (SEMA) 6 (Aralık 2021), 1-20. https://doi.org/10.47702/sema.2021.12 


\section{GİRIŞ}

Denizli tarih boyunca önemli medeniyetleri bünyesinde barındırmış, mümbit arazisi, ılıman iklimi ve stratejik konumu ile her zaman dikkatleri üzerine çekmiş kadim şehirlerden birisidir. Pamukkale dâhil, sahip olduğu eşsiz coğrafyası sebebiyle en eski dönemlerden beri insanların önemli yaşam merkezleri arasında yerini almıştır. Nitekim Beyce Sultan Höyüğü ve Ekşi Höyükteki buluntular, insanlık tarihinin en eski izlerini taşımaktadır. ${ }^{1}$ Yine Colosseia, Tripolis, Hıereapolis ve Laodikeia gibi bünyesinde çok önemli medeniyet merkezlerini barındırıyor olması ${ }^{2}$ Bizans döneminde de aynı güçlü stratejik yapıya sahip olduğunun kanıtıdır.

Denizli ve çevresi, bahsettiğimiz özellikleri ile Türklerin de hemen dikkatini çekmiştir. Nitekim 11. yüzyllda bölgenin en önemli iki merkezi olan Colossiea ve Laodikeia, Türkmenler tarafından çok erken dönemlerden itibaren yağmalanmaya başlanmıştır. Afşin Bey'in, Colosseia'yı (Honaz) ilk yağmalaması 1069 yılındadır ki ${ }^{3}$ daha Malazgirt savaşından iki yıl önce Türk akıncılarının bölgeye gelmesi bu bölgenin aslında o dönemde de bir çekim merkezi olduğunu ortaya koymaktadır.

Bizans İmparatorluğu da bu bölgenin avantajlarının farkındadır. $\mathrm{O}$ da böylesine önemli bir coğrafyayı elinde tutabilmek ve buraları Türklere terk etmemek için oldukça fazla mücadele etmiştir. Nitekim Denizli ve çevresi uzun süre Bizans'ın, Türkmen akınlarına karşı bir nevi son savunma hattını oluşturmuştur. Selçuklular da Denizli ve çevresine hâkim olabilmek ve buralarda kesin egemenliklerini tesis edebilmek için hayli emek harcamıştır.

\section{Haçlı Seferlerine Kadar Denizli ve Çevresinin Siyasi Yapısı}

Bilindiği gibi Selçuklular, Dandanakan savaşının kazanılmasından sonra yoğun bir Türkmen muhaceretine maruz kalmıştı. ${ }^{4}$ Genç Selçuklu Devleti, İslam dinini yeni kabul eden ve yeni bir din kabul etmenin motivasyonuna sahip bu kitleleri kendi topraklarında tutmak yerine; İran üzerinden Anadolu'ya kanalize etmişti. İran coğrafyasında önemli bir yoğunluğa ulaşan Türkmenler, yavaş yavaş Anadolu'ya girmeye başladılar. Şartların da müsait olmasına bağlı olarak ${ }^{5}$ Türkmen kitlelerinin Anadolu'daki yağma hareketleri kısa sürede oldukça büyük boyutlara ulaştı. Belki de Türkmenlerin bile öngöremediği bir hızda gelişen bu ilk akınlarla Anadolu, doğudan batıya Selçuklu akıncıları tarafından yağmalanmaya başlandı. Malazgirt savaşının hemen sonrasında Batı Anadolu'daki

\footnotetext{
${ }^{1}$ Beyce Sultan ile ilgili olarak bk. Eşref Abay - Fulya Dedeoğlu, "Beyce Sultan 2007 - 2008 Yılları Kazı Çalışmaları Ön Raporu”, Arkeoloji Dergisi 13 (2009 /1), 53-79. Ekşi Höyük ile ilgili olarak bk. Fulya Dedeoğlu vd., "Ekşi Höyük 2015 Kazı Çalışmaları", 38. Kazı Çalışmaları Toplantısı (23 - 27 Mayıs 2016 Edirne) II (Ankara: 2017), 389-402.

${ }^{2}$ Bu merkezlerle ilgili olarak bk. Kemal Şakir, Tarihi, Coğrafi, İctimai, Sihhi, İktisadi Nokta-i Nazardan Denizli, nşr. İbrahim Balık (Denizli: Büyükşehir Belediyesi Yayınları, Denizli 2010), 10 vd.

3 Osman Turan, Afşin Beyin Honaz’ı yağmalamasını 1069 yılı olarak kabul etmektedir. Osman Turan, Selçuklular Zamanında Türkiye Tarihi (İstanbul: Nakışlar Yayınevi, 1984), 20. Tuncer Baykara ise bu olayın tarihini 1070 olarak belirtir. Tuncer Baykara, Selçuklular ve Beylikler Çağında Denizli 1070 - 1520 (İstanbul: IQ Yayınlar, 2007), 35.

${ }^{4} \mathrm{Bu}$ yoğun Türkmen göçü ilk anda Selçukluların lehine olmuş ve Gaznelilere karşı giriştiği bağımsızlık mücadelesinde insan unsuru sıkıntısı yaşamamıştır. Ancak, özellikle Dandanakan savaşının kazanılması ile bir anda bölgede en büyük güç haline gelen Selçuklu ülkesine yönelik çok fazla Türkmen göçü yaşanmaya başlandı. Gelen Türkmen kitlelerinin oluşturmaya başladığı sıkıntının farkına varan Tuğrul Bey, güzel bir çözüm ile bu kitleleri Selçuklu topraklarında tutmak yerine, İran üzerinden Anadolu'ya göndermeye başladı. Hem kendisi için önemli bir problem haline gelmeye başlayan bu yoğun Türkmen göçünden kaynaklanan sıkıntıları çözmüş oldu hem de ileride hâkimiyet kurmak istediği Anadolu'nun fethi için zemin oluşturmaya başladı.

5 Bizans'ın içinde bulunduğu siyasi bunalımlar ve özellikle Balkanlar'daki Peçenek ve diğer unsurlarla yapılan yoğun mücadeleler Bizans'ın dikkatini ister istemez Anadolu'dan Balkanlara çevirmişti. Bu konuda bk. E. Gregory Timothy, Bizans Tarihi, çev. Esra Ermen (İstanbul: Yapı Kredi yayınları, 2019), 90.
} 
Türkmen akınları Ege kıyılarına kadar ilerledi. Nitekim 1073 y1lında Milet (Miletos) önlerinde Türkmenler görülmeye başlandı. ${ }^{6}$ Bölgenin 1lıman iklimi Türkmen kitlelerinin sürüleri için, İç Anadolu'nun çalılık arazilerine oranla çok daha zengin otlaklar sunmakta idi. ${ }^{7} \mathrm{Bu}$ durum Türkmen kitlelerini uç bölgelere yönelten etkenlerden birisi olmuştur.

Türkmen kitleleri ve Selçuklu yöneticileri Anadolu'yu, sadece yağma yapıp ganimet devşirilen münbit bir coğrafya olarak görmedi. Onların devlet adamlığı konusunda doğuştan gelen yetenekleri Anadolu'ya başka gözle bakmalarını sağladı. Bu toprakların efendileri olmayı hayati bir gaye haline getirdiler. Buna bağlı olarak Anadolu'ya artan sayıda gelen askeri unsurlarla güçlerini kısa sürede artırdılar ve bu toprakların efendileri haline gelmeye başladılar. ${ }^{8}$

Süleyman Şah, kısmen Ebul Kasım ve I. Kılıç Arslan dönemlerinde siyasi istikrarın tam olarak tesis edilememesi, Türkmen kitlelerinin Denizli ve çevresine tam olarak hâkim olmalarını sekteye uğrattı. I. Kılıç Arslan'ın Batı Anadolu'da Selçuklu otoritesini yeniden tesis etmeye çalıştığı sırada ise I. Haçlı Seferi gerçekleşti. Bu sefer, Denizli ve çevresinin Selçuklu hâkimiyeti altına girme sürecini epeyce ötelemiş oldu. Nitekim Claude Cahen bu konuda şu ilginç değerlendirmeyi yapmıştır: “Ĕger Haçlı Seferleri olmasaydı Türkler belki de 14. Yüzyılda klyılarda gördü̈̆̈̈müz beyliklerin topraklarına o zaman (1073 - 1075) yerleşeceklerdi."

\section{I. Haçlı Seferinin Denizli ve Çevresinin Siyasi Yapısına Etkisi}

Tarihin kaydettiği en büyük din savaşlarından birisi olan Haçlı Seferleri, siyasi, kültürel, ekonomik ve dini pek çok sebebin bir araya gelmesi ile gerçekleşmiştir. ${ }^{11}$ Temel hareket noktası, Hıristiyan dünyasının en önemli kutsallarından birisi olan Kudüs'ü ve diğer dini mekânları (Antakya, İznik vs) Müslümanların elinden kurtarmak olan Haçlı Seferleri, ilk anda Anadolu'da önemli siyasi değişimler meydana getirmiştir. ${ }^{12}$ Özellikle I. Haçlı Seferi, Bizans için çok önemli kazanımlar sağlarken, Anadolu'da siyasi hâkimiyetini tesis etme aşamasındaki Selçuklular için ise önemli kayıplara sebep olmuştur. Her ne kadar Bizans'ın Haçlıları Anadolu'ya davet edip etmediği konusu tartışılan bir konu ise de ${ }^{13}$ bu seferlerden ilk anda en kazançlı çıkan devlet Bizans gibi görünmektedir.

Haçlı orduları İstanbul önlerine geldiğinde İmparator Alexis, onlarla bir anlaşma yapmayı başarmıştı. Buna göre Haçlılar Anadolu'da aldıkları yerleri Bizans'a bırakacak, buna karşılık Bizans ta Haçlılara bilmedikleri Anadolu topraklarında kılavuzluk yapacak ve lojistik destek verecekti. İlk Haçlı Seferi, Bizans'a beklediğinden daha fazlasını verdi. Nitekim Haçlılar, I. Kılıç Arslan'1 önce Eskişehir

\footnotetext{
${ }^{6}$ Bu konuda daha geniş bilgi için bk., Muharrem Kesik, 1071 Malazgirt (İstanbul: Timaş Yayınları, 2014); Claude Cahen, Osmanlılardan Önce Anadolu, çev. Erol Üyepazarcı (İstanbul: Tarih Vakfı Yurt Yayınları, 2000); Charles Diehl, Bizans Imparatorluğu Tarihi, çev. Selim Sezer (İstanbul: İnkılap Yayınevi, 2018) 134; Ali Sevim, Anadolu'nun Fethi Selçuklular Dönemi (Ankara: Türk Tarih Kurumu Yayınları, 2020) 84.

7 John Julıus Norwich, Bizans-3 Gerileme ve Çöküş Dönemi (MS 1082 - 1453) çev. Selen Hırçın Riegel (İstanbul: Kabalc1 Yayınevi, 2013), 83.

${ }^{8}$ Tamara Tilbot Rice, Anadolu Selçuklu Tarihi, çev. Tuna Kaan Taştan (Ankara: Nobel Yayınevi, 2015), 56.

${ }^{9}$ Süleyman Şah'ın Suriye seferine çıkarken yerine İznik’te bıraktığı komutandır. Ebu'l-Kasım, Süleyman Şah'ın Suriye seferinde hayatını kaybetmesinden sonra İznik'i yönetmeye başlamıştır.

${ }^{10}$ Cahen, Osmanlilardan Önce Anadolu, 12.

${ }^{11}$ Haçlı seferlerinin düzenlenme sebepleri ve Hristiyan toplumunun Müslümanlara ve Türklere bakış açısı ile ilgili güzel bir değerlendirme için bk. Işın Demirkent, "Haçlı Seferi Düşüncesinin Doğuşu ve Hedefleri”, İ̈EEFTD 35 (1994) 65-78. Ayrıca, Şaban Ali Düzgün, “ İki Dünyanın Karşılaşması: Müslüman ve Latin Batı Dünyası Arasında Haçlı Seferleri Dönemindeki İlişkiler”, İslami Araştırmalar Dergisi 14/3-4 (2001) 349-360

${ }^{12}$ Haçlı Seferlerinin sebepleri ile ilgili olarak bk. Salim Koca, "Haçlı Seferleri Sebep ve Sonuçları Bakımından Nasıl Değerlendirilebilir", Akademik Bakış, 10/20, (2017) 16-35; Ayrıca Haçlı Seferleri ile ilgili güzel bir değerlendirme için bk., Anonim Haçlı Tarihi, yay. Ergin Ayan (İstanbul: Selenge Yayınları, 2013), 25 vd.

${ }^{13} \mathrm{Bu}$ konuda farklı bir yaklaşım için bk, Georg Ostrogorsky, Bizans Devleti Tarihi, çev. Fikret Işıltan (Ankara: Türk Tarih Kurumu, 2019, 335.
} 
Dorylion'da, sonra da Konya Ereğli'de yenip Selçuklu ülkesini terk ederken; Selçuklular da başkentleri İznik dâhil, Marmara ve Ege topraklarının büyük bir kısmını bırakıp daha iç bölgelere çekilmek zorunda kaldı. Bunun sonunda Selçuklular genel anlamda Eskişehir, Bolvadin, Akşehir, Denizli ve Antalya hattının doğusuna çekilmiş oldu. ${ }^{14}$

Ancak özellikle Ege'deki çekilmenin şeklen bir çekilme olduğunu rahatlıkla söyleyebiliriz. Çünkü zaman zaman Selçuklu Devletinin de üzerlerinde tam hâkimiyet sağlayamadı̆̆ı Türkmen unsurlar, bu bölgeleri tam olarak boşaltmadı. Haçlıların gelişi ile Türkmen kitlelerinin sağa sola dağılmaları onların buralarda yok edildiği anlamına gelmiyordu. Haçlıların arkasından gelen Bizanslılar, ancak Batı Anadolu'nun bazı önemli vadilerini ele geçirebilmişlerdi. Hatta I. Kılı̨̧ Arslan, Efes’teki son Türk kalesini ancak 1107'de, (Danişmendlilerle düştüğü bir anlaşmazlığa bağlı olarak) Bizans İmparatoru Alexis ile yakın ilişkiler kurması üzerine yıkmışt. ${ }^{15}$

Diğer taraftan, Bizans'ın da Haçlı Seferleri ile ilgili memnuniyeti uzun süreli olmadı. Haçlıların özellikle Anadolu'nun güneyi ve Suriye'nin kuzeyinde kurdukları hâkimiyet, Bizans için de kendi egemenlik sahasına tecavüz anlamına geliyordu. Hatta Bizans, bu çerçevede bölgedeki Müslüman unsurlarla ve Selçuklularla işbirliği arayışından da çekinmedi. Nitekim Haçlı komutanı Tancred'in, Antakya şehrinin kontrolünü ele geçirmesi, Bizans'ın bölgedeki hâkimiyetini zedeleyen önemli bir gelişme idi. Bunun üzerine Bizans imparatoru Alexis, Selçuklularla bir askeri ittifak arayışına girişti. ${ }^{16}$

Haçlılarla, Bizans arasında I. Haçlı Seferinden hemen sonra başlayan karşılıklı güvensizlik diğer seferler de daha da artarak devam etti. Özellikle II. Haçlı Seferi sırasında bu durum daha belirgin hale geldi. ${ }^{17}$

\section{II. Haçlı Seferine Kadar Selçukluların Denizli ve Çevresinde Yeniden Hâkimiyet Kurma Çalışmaları}

Yukarıda da anlatmaya çalıştığımız gibi Bizans, I. Haçlı Seferi sonunda kısmen de olsa Ege kıyılarından başlayıp; Türkmenlerin daha güçlü olduğu iç bölgelere doğru etkisini yitiren bir hâkimiyet tesis etmişti. Ancak Selçuklular, I. Haçlı Seferinin tesirinden kurtulmaya başladıktan hemen sonra, Batı Anadolu'daki egemenlik sahasını geniş̧leterek tekrar bölge üzerinde söz sahibi olmayı istediler. Bunun için aslında şartlar belki de ilk fetih döneminden daha müsait durumda idi. Çünkü Ege Bölgesinde, kıyıdan içerilere doğru uzanan ovalar ile bunların kuzey ve güneyindeki bol otlaklı dağlar, Türkmenler tarafindan tamamen boşaltılmamıştı. ${ }^{18}$ Yani bu bölgede zaten bir Türkmen varlığı mevcuttu. Dolayısıyla Selçuklular ilk fetih döneminden daha avantajlı bir durumda, tekrar Batı Anadolu hâkimiyetini güçlendirmeye başlamış oldu. Ancak Selçukluların bir anlamda Batı Anadolu uç politikasının en önemli bölümünü teşkil eden Denizli ve çevresinde tam hâkimiyet kurabilmeleri neredeyse I. Giyaseddin Keyhüsrev dönemine kadar sürecek uzun soluklu bir mücadeleyi gerektirmiştir.

Selçukluların Batı Anadolu'da hâkimiyetlerini yeniden tesis etme çalışmaları, daha Şahin Şah'ın sultanlığı döneminde başlamıştı. 1110 yılında üçüncü Selçuklu sultanı olarak tahta çıkan Şahin Şah, aynı yıl Kıyı Ege ile İç ege arasındaki iletişimde çok stratejik bir noktada bulunan ve o yıllarda bölgenin önemli yerleşim merkezlerinden birisi olan Alaşehir (Philledlephia) üzerine ordu gönderdi.

\footnotetext{
${ }^{14}$ Ebru Altan, "Haçlı Seferleri ve Anadolu (1097 - 1190): Türkiye Selçukluları Tarihinde Haçlı Seferlerinin Yeri ve Önemi”, USAD 12 (Bahar 2020), 40.

${ }^{15}$ Chaen, Osmanlidan Önce Anadolu, 15.

${ }^{16}$ Timothy, Bizans Tarihi, 297

${ }^{17}$ Salim Koca, Haçlı Seferleri Sebep ve Sonuçları, 24.

${ }^{18}$ Chaen, Osmanlıdan Önce Anadolu, 15; Altan, Haçlı Seferleri ve Anadolu, 43.
} 
Kaynaklardan edindiğimiz bilgilere göre bu ilk harekette istediği başarıyı elde edemeyen Şahin Şah, Bizans ile bir anlaşma imzalamak durumunda kaldı. Buna rağmen bu hareket Türkmenlerin Bizans aleyhine daha güvenle harekete geçmesine sebep oldu. Nitekim 1113 yılında Bizans sınırlarını aşan Türkler, İznik ve Edremit'e kadar akınlarını ilerlettiler. ${ }^{19}$

Şahin Şah döneminde başlayan bu mücadele 1116 yılına kadar devam etti. Bu yıl Bizans İmparatoru Alexis Kommenos, Afyonkarahisar yakınlarına kadar ilerleyebilmişti. Ancak burada yaptığı mücadeleyi kaybeden imparator, oldukça zor bir durum düştü. Tam bu sırada beklenmedik bir şekilde Şahin Şah, Bizans imparatoruna anlaşma teklif etti. Bunu memnuniyetle kabul eden imparator anlaşmayı imzalayıp geri döndü. ${ }^{20}$ Şahin Şah'ı avantajlı bir durumda iken İmparator Alexis ile anlaşma yapmaya zorlayan faktör ise kardeşi Mesut'un, kendini tahttan indirmek için harekete geçmesi idi. Nitekim kardeşi Mesut ile giriştiği bu mücadele, Şahin Şah'ın önce gözlerini sonra da hayatını kaybetmesine sebep olmuştur.

Selçuklu Devletinde yaşanan bu taht değişikliğinden çok kısa bir süre sonra 1118 y1lında Bizans'ta da bir hükümdar değişikliği yaşanmıştır. Alexis Kommenos ölmüş ve yerine Anadolu'da Bizans hâkimiyetini yeniden tesis etmek ve Malazgirt öncesi sınırlara yeniden egemen olabilmek gibi; çok iddialı bir söylemi kendine hedef haline getiren Ioannes Kommenos tahta geçmiştir.

Ioannes, batıdaki durgunluk ve Bizans aleyhine her hangi bir harekette bulunulmamasından faydalanarak dikkatini Anadolu'ya çevirme firsatı bulmuştur. Anadolu'da Sultan Mesut ve Danişmendli Emir Gazi iki büyük güç idi ve Türkmenler çoğunlukla bu ikisinin emri altında idi. Bu Türkmen kitlelerinin batıdaki uç bölgelerine yönlendirilenleri, yukarıda da bahsettiğimiz gibi daha Alexios'un hâkimiyetinin ikinci yarısında, Ege Bölgesinin iç kesimlerindeki verimli ovalara sızmaya başlamışlardı. Onların bu faaliyetleri Bizans'ın Antalya limanı ile kara bağlantısını kesmişti. Bizans Devleti, bu önemli liman şehri ile sadece deniz yolu ile iletişim kurabiliyordu. ${ }^{21}$ Bu durum Bizans için büyük bir handikap idi. Bunun için Ioannes'in halletmesi gereken önemli meselelerden birisi, kendisi için Antalya yolunu güvenli hale getirmek, Denizli ve Isparta bölgelerinde tekrar hakimiyetini tesis etmek olmuştur.

Bizans'taki bu taht değişikliğinden istifade eden Türkler, I. Haçlı Seferinden sonra Bizanslılar tarafindan ele geçirilen yerleri istirdada başladılar. Bu çerçevede bölgenin en önemli merkezlerinden birisi olan ve bu günkü Denizli şehrinden 6 km uzakta bulunan Laodikeia'yı da ele geçirdiler. Son derece esnek bir sınırda yer alan bu önemli yerleşim merkezi bölgedeki çoğu köy ve kasaba gibi tekrar Türklerin kontrolüne geçmiş oldu. ${ }^{22} \mathrm{Bu}$ gelişme üzerine yeni imparator Ioannes, hemen harekete geçti. ${ }^{23} 1119$ yılında Bizans'ın o dönemdeki şöhretli komutanlarından birisi olan Türk asıllı Akkuş ${ }^{24}$ komutasındaki kuvvetleri Alaşehir üzerinden Laodikeia'ya gönderdi. Bu bölgenin Selçuklu valisi olan,

\footnotetext{
${ }^{19}$ Turan, Selçuklular Zamanında Türkiye, 154.

${ }^{20}$ Yusuf Ayönü, "Selçuklu - Bizans Münasebetleri (1116- 1308)" (İzmir: Ege Üniversitesi, Sosyal Bilimler Enstitüsü, Doktora Tezi, 2007), 25. Claude Chaen bu anlaşma sırasında Şahin Şah'ın, Bizans İmparatorluğunun sınırlarını Romanos Diogones'in zamanındaki durumuna getirmeye söz verdiğini ve Türkleri bu sınırların ötesine çekmeyi vadettiğini söyler. Chaen, Osmanlılardan Önce Anadolu, 21.

${ }^{21}$ Norwich, Bizans-3, 83.

${ }^{22}$ M. V. Levtchenko, Kuruluşundan Yıkılışına Kadar Bizans Tarihi, çev. Maide Selen (İstanbul: Özne Yayınları, 2007), 198; Norwich, Bizans-3, 83-84.

${ }^{23}$ Muharrem Kesik, Türkiye Selçuklu Devleti Tarihi Sultan I. Mesut Dönemi (116-1155) (Ankara: Türk Tarih Kurumu, 2003), 51.

${ }^{24}$ Akkuş (Aksukhos), Ioannes Kommenos’un en güvendiği kişilerden birisidir. Türk asıllı olan Akkuş, I. Haçlı Seferi sırasında esir alınıp dönemin Bizans İmparatoru Alexıos Kommenos'a hediye edilmiştir. Sarayda eğitilen Akkuş, prensliği döneminde Ioannes'in en yakın arkadaşlarından birisi olmuştur. Ioannes imparator olunca çok güvendiği bu dostunu hızla yükseltmiş ve orduların başkomutanı yapmıştır. Norwich, Bizans-3, 82.
} 
birçok savaşta ün kazanmış ve en az 800 önemli kişi ile şehri savunan ${ }^{25}$ Emir Başara'y1 ${ }^{26}$ mağlup etti. Böylece Laodikeia'yı ele geçiren Bizanslılar; tekrar Türklerin eline geçmemesi için şehri yeni bir sur ile çevirip gerekli erzak ve malzeme ile teçhiz ettiler. ${ }^{27}$

$\mathrm{Bu}$ arada Selçuklularda uzun süreden beri devam eden taht mücadelesi sona ermiş ve Sultan Mesut tahta geçmişti. Sonraki yıllarda, Sultan Mesut'un otoritesini artıracak önemli bir gelişme daha meydana geldi. Bu gelişme, o dönemde Anadolu'nun en büyük siyasi otoritelerinden birisi olan Danişmendlilerin güç kaybetmesi ve Sultan Mesut'un bu durumu kendi avantajına çevirebilmiş olmasıdır. Nitekim Danişmendlilerin efsanevi lideri Emir Gazi'nin ölümünden sonra yerine geçen oğlu Muhammet ile ittifak yapan I. Mesut, ${ }^{28}$ Bizans'a karşı tekrar üstünlük kurdu ve İstanbul - Antalya yolu üzerindeki Uluborlu'yu (Sozopolis) yeniden Selçuklu sınırlarına kattı. ${ }^{29}$

Uluborlu'nun Selçukluların eline geçmesi Bizans için büyük bir sıkıntı oluşturdu. Zira bu şehir İstanbul-Antalya yolu açısından büyük bir ehemmiyet arz ediyordu. Ayrıca iç bölgelerden, Anadolu'nun batısına geçişte oldukça kilit bir noktada idi. Buranın Selçukluların eline geçmesi, Bizans'ın Batı Anadolu hâkimiyetini ciddi şekilde tehdit etmekte idi. Ioannes, Uluborlu'yu ve müstahkem mevkileri ele geçirmek için bölgeye bir sefer düzenledi. Uluborlu ele geçirilmesi zor bir kale idi ve Ioannes’te bunun farkında idi. Birliklerinin çoğunu gizleyen Ioannes, az bir kuvvetle kaleye saldırdı ve müdafilerin bu az sayıdaki Bizans ordusunun saldırısını püskürtmek için kaleden çıkmasını sağladı. Daha sonra pusuda bekleyen asıl kuvvetleri ile Uluborlu'yu savunan Türk birliklerini kolayca imha etti ${ }^{30}$ ve bu stratejik noktaya tekrar hâkim oldu. ${ }^{31}$ İmparator buradan yoluna devam ederek birçok müstahkem kaleyi ele geçirip Antalya'ya ulaştı. ${ }^{32}$

Bizans İmparatorluğunun en ihtiraslı ve idealist hükümdarlarından birisi olan Ioannes Kommenos, ${ }^{33}$ Çukurova'daki bir av sırasında vefat etti. ${ }^{34}$ Yanında bulunan oğlu Manuel, babasının cesedini deniz yolu ile İstanbul'a gönderdikten sonra kendisi de ordusunun başına geçip izin istemeksizin Türk topraklarının ortasından geçip İstanbul'a vard1. ${ }^{35} \mathrm{Bu}$ yolculukla ilgili ayrıntılı bilgi veren Niketas, Manuel'in Honaz (Khonai) şehrinden geçtiğini ve buradaki Mikhail Kilisesini ziyaret ettiğini yazmaktadır. Hatta Honaz'ın başpiskoposu O'nu takdis etmiş ve İstanbul'a ulaşıp Bizans tahtına geçeceğini müjdelemiştir. ${ }^{36}$ Işın Demirkent, çevirisini yaptığı Kınnamos'un Hıstorıa (1118 -

\footnotetext{
${ }^{25}$ Ioannes Kinnamos, Historla $(1118$ - 1176), yay. Işın Demirkent (Ankara: Türk Tarih Kurumu Basımevi, 2001), 6.

${ }^{26}$ Tuncer Baykara Bizans kaynaklarında (Picharas) şeklinde yazılan bu ismi Alp Kara olarak telaffuz etmektedir. Tuncer Baykara, Denizliye Dair Yazılarım (Denizli: Denizli Büyükşehir Belediyesi Yayınları, 2019), 102. Kinnamos'un Türkçe tercümesinde de Alp Kara olarak geçmektedir. Kinnamos, Historia, 6; Norwich ise Laodekeia'nın bu ilk Türk komutanının adını Ebu Şara olarak kaydetmiştir. Norwich, Bizans-3, 83.

${ }^{27}$ Kinnamos, Historia, 6; Niketas Khoniates, Historla (İoannes ve Manuel Kommenos Devirleri), çev. Fikret Iş1ltan (Ankara: Türk Tarih Kurumu, 1995), 8; Norwich, Bizans-3, 83; Chaen, Osmanlılardan Önce Anadolu, 21.

${ }^{28} \mathrm{Bu}$ ittifak ile ilgili olarak bk. Kesik, I. Mesut Dönemi, 77.

${ }^{29}$ Chaen, Osmanlilardan Önce Anadolu, 27.

${ }^{30}$ Ioannes'in Uluborlu'yu ele geçirirken uyguladığı taktikle ilgili bk. Kesik, I. Mesut Dönemi, 52; Ayönü, Selçuklu-Bizans Münasebetleri, 31.

${ }^{31}$ Niketas, Historia, 9.

${ }^{32}$ Kinnamos, Historia, 7.

${ }^{33}$ Bilindiği gibi Ioannes Toroslar bölgesinde seferde iken, önce oğlu Alexıos vefat etmiştir. Onun cenazesini İstanbul'a gönderen Ioannes, cenaze alayı İstanbul'a ulaşamadan diğer oğlu Andronıkos'un da öldüğünün haberini almıştır. Bu iki büyük acıya rağmen güneydeki seferinden vaz geçmeyen Ioannes te aynı yıl Çukurova'da bir av partisinde kendini zehirli okla kazara yaralamış ve bu yaradan kurtulamayıp vefat etmiştir.

${ }^{34}$ Ostrogorsky, Bizans Devleti Tarihi, 351.

${ }^{35}$ Kinnamos, Historia, 29.

${ }^{36}$ Niketas, Historia, 152.
} 
1176) isimli esrinde Manuel'in Istanbul'a dönüş yolculuğu ile ilgili kısımdaki dip notta, bölgedeki Türk hakimiyeti konusunda şu bilgileri vermektir. " Kınnamos, bu yolun 'Manuel'in İstanbul'a dönerken kullandiğı yol' Türk topraklarının ortasından geçtiğini söylemekle bu bölgede artık, Bizans hâkimiyetinin bulunmadığını açıkça ifade etmektedir. Halbuki imparator Ioannes ölümünden bir yıl önce 1142'de Antakya'ya giderken Frig bölgesinin doğusundan, Beyşehir Gölü yoluyla ilerlemiş ve o bölgedeki Selçuklu üstünlügünü kırmak istemişti. Ama Kınnamos'un kaydından çıkan sonuca göre bu çaba boşuna olmuş ve sadece Beyşehir Gölü civarı değil, Frigya bölgesine bile Türkler hakim olmuşlardı. Imparatorluk bu bölgelerde ancak kuvvetli tahkimata sahip bazı kale ve şehirleri elinde tutabilmekteydi. O halde bu dönemde Selçukluların bu bölgelere yaptıkları akınların sadece henüz ele geçmemiş şehir ve kaleler üzerine düzenledikleri taarruzlar olarak değerlendirilmesi gerektiğini düşünüyorum." ${ }^{37} \mathrm{Bu}$ değerlendirmeden de anlaşıldığı üzere, bu dönemde Selçuklularla - Bizans arasında sabit bir sınırdan bahsetmek asla mümkün değildir. Her iki devlette kendilerine göre bir hâkimiyet alanı belirlemeye çalışsa bile özellikle uç bölgeler olarak tabir edilen Denizli ve çevresinde Türkmenlerin akın ve yağmaları bu sınır kavramını tamamen geçersiz kılmaktadır. Nitekim bir yıl içinde bile Bizans'ın kendine ait zannettiği topraklar, Türk egemenlik sahasının ortası haline gelebiliyordu. Dolayısıyla, II. Haçlı seferi sırasında, aşağıda değineceğimiz şekilde, Fransız birliklerinin Efes'ten ayrıldıktan kısa süre sonra Türk taarruzuna maruz kalmasını ve Denizli'ye yaklaştıkça bu taarruzların yoğunluğunu artırmasını yadırgamamak gerekir.

İmparator Ioannes Kommenos'un, Anadolu'daki Selçuklu hâkimiyetini kırmak hevesi, yerine geçen oğlu Manuel Kommenos’ta da devam etmiştir. Ioannes dönemindeki baskı ve seferlere rağmen, Türk akınlarının kuzeyde İznik - Eskişehir arasındaki Malangeia bölgesine, güneyde ise Menderes Ovasına ve Ege kıyılarına kadar uzanması engellenemedi. Bu yüzden Manuel, tahta çıktıktan sonra Türk akınlarını durdurmak, sınır bölgelerinin güvenliğini sağlamak amacıyla bu bölgede yeni kaleler ve müstahkem mevkiler inşa etmiştir. ${ }^{38}$

Bizans'ın yeni imparatoru, Anadolu'da Bizans hâkimiyetini tesis etme konusunda babasından aşağı kalmadığını ortaya koymak istiyordu. Bunun için babasının askeri planlarını devam ettirmeye çalıştı. Nitekim 1146 'da Menderes vadisi yolu ile Konya'ya doğru yeni bir sefere çıktı. ${ }^{39}$ Aslında kendisi açısından bakıldığında bu sefere çıkmasını haklı kılacak gerekçelere sahipti. Çünkü Sultan I. Mesut, hemen hemen deniz kıyısına ulaşacak kadar Menderes vadisine girmiş bulunuyordu. ${ }^{40} \mathrm{Bu}$ sefer sırasında Denizli'nin hemen kuzeyinde, Çivril yakınlarında bazı mücadeleler oldu. Konya'ya kadar ilerleyen Manuel ciddi bir başarı elde edemeden geri döndü ve geri dönerken menderes vadilerinde tekrar Türkmen saldırılarına uğradı. ${ }^{41}$

Manuel Kommenos'un, 1146 yılında çıktığı ve Konya'ya kadar ilerlediği bu seferinde Eskişehir, Afyon, Akşehir üzerinden Konya'ya ulaştığı bilinmektedir. Ancak kaynaklardaki ifadelerden net bir şekilde anlaşılmaktadır ki; O’nun Konya'ya kadar ulaşmış olması daha güneyde bulunan Denizli havalisindeki Türkmen hareketliliği ve gücü üzerinde hiçbir olumsuz tesir icra etmemiştir. Nitekim Manuel'in Konya seferinden dönüş yolunda yaşadığı ve Kinnamos'un eserinde detaylı bir şekilde anlattığı, şu olay, durumu net bir şekilde ortaya koymaktadır. " Imparator Mainandros'un (Büyük Menderes) kaynaklarından birine varınca Apaemia (Dinar) ile Khoma (Homa) arasında artık düşman topraklarının dışına çıktığını zannetti. Burasının suyu bol ve insanın gözüne çok hoş görünen bir yer olduğunu fark ederek savaşın verdiği sikıntıyı avlanmanın eğlencesi ile

\footnotetext{
${ }^{37}$ Kinnamos, Historia, 29 (5 numaralı dipnot.)

${ }^{38}$ Ebru Altan, II. Haçlı Seferi (1147 - 1148) (Ankara: Türk Tarih Kurumu, 2003), 41

${ }^{39} \mathrm{Bu}$ sefer sırasında yaşananlarla ilgili olarak bk. Ayönü, Selçuklu-Bizans Münasebetleri, 52 vd.

${ }^{40}$ Steven Ruciman, Haçlı Seferleri Tarihi, çev. Fikret Işıltan, (Ankara: Türk Tarih Kurumu, 2008), 2/220

${ }^{41}$ Timothy, Bizans Tarihi, 303; Chaen, Osmanlılardan Önce Anadolu, 30.
} 
üzerinden atıp gevşemek istedi. Fakat uzaktaki bitki örtüsü içinde bir hareket gördü. Ancak mesafenin uzaklığından dolayı gördüğ̈̈nün ne olduğunu tespit edemediğinden adamlarından birkaç kişsiyi araştırmaya yolladı ve orada bir çadır kurulmuş olduğunu öğrendi. Çalılıklar arasındaki hareket çadırlar içinde bulunanların atlarına aitti. Gemsiz ă̆ızlarıyla otluyorlardl. Derhal bu Türkmenlerin kimler olduğunu anladl, onları kabilelerine göre adlandırdı. Bunlar adetleri üzere komşu Romalıları yağmalamaya gelmişlerdi ve şimdi bol bol ganimetlerle yüklüydüler ... ",2

Görülen o ki; Ioannes Kommenos zamanında Bizans sınırı Uluborlu'ya kadar ilerletilmiş ve bu önemli garnizon Bizans egemenliğine alınmışsa da bu sembolik bir hâkimiyet olarak kalmıştır. Kinnamos'un yukarıda bir bölümünü verdiğimiz anlatımlarından ve Manuel'in 1146 seferi dönüşünde menderes vadisinde yaşadığı diğer sıkıntılardan anlaşıldığı gibi özellikle Afyon'un güneyinde kalan bölgede, Bizans hakimiyeti nerede ise yok gibiydi. Bizans İmparatoru, Selçukluların Başkenti Konya'ya kadar uzanan bir sefer düzenlemiş olmasına rağmen; Bizans ordusunun dönüş yolunda uğradığı güneydeki bölgelerde Türkmenler varlıklarını sürdürmekte idi. Hatta Bizans imparatorunun Denizli havalisinden geçiyor olması bile buradaki Türkmenleri hiç endişelendirmemiş ve yukarıdaki anlatımda da gördüğümüz gibi pervasızca davranabilmişlerdir.

Bütün istek ve gayretine rağmen hem Ioannes ve hem de oğlu Manuel, iç bölgeler şöyle dursun; Anadolu'nun batısında bile istedikleri başarıyı elde edemediler. Sadece sahil bölgeleri Türk akınlarından masun kalabildi. Onun dışındaki Batı Anadolu toprakları, sürekli Türkmen akınlarına maruz kalmıştır. Sınır boylarındaki Bizans ahalisi ya köylerini terk etmiş ve bölgedeki büyük şehirlere göç etmiş ya da kıyılara kaçmıştı. ${ }^{43}$ Konumuzu teşkil eden Denizli yakınlarında bulunan ve aynı şekilde bakımsız bırakılan Laodikeia'da ki Rum ahali de kısmen şehri terk etmeye başlamıştı. ${ }^{44}$

\section{Hâkimiyeti}

4. II. Haçlı Seferi Sırasında Denizli Havalisinde Yaşananlar ve Bölgedeki Türk

I. Haçlı Seferi sonunda, Güneydoğu Anadolu ve Suriye'de kurulan kontluklar nerdeyse kurulduğu dönemden beri sürekli bölgedeki diğer unsurlar tarafından baskı altına alınmaya çalışılmıştır. ${ }^{45}$ Musul Atabeyi Nureddin Zengi de, bölgede Haçlılara karşı mücadele eden önemli unsurlardan birisi idi. 1144 yılında Ura Haçlı Kontluğu üzerine büyük bir sefer düzenledi. Üç haftadan fazla süren kuşatmanın sonunda Nureddin 24 Aralık 1144'te Urfa'yı ele geçirdi. Yaklaşık elli yıllık aradan sonra Urfa'nın tekrar Türklerin eline geçmesi ve kurulan ilk Haçlı Kontluğunun yıkılmış olması, Avrupa'da kısmen sönmüş olan Haçlı seferi heyecanını yeniden uyandırdı. ${ }^{46}$

Bu heyecan firtınası karşılığını hemen buldu ve Alman Kralı III. Konrad ile Fransa Kralı VII. Louis yeni bir haçlı seferinin düzenleyici amili haline geldiler. Haçlı ordularının kumandanlığını üstlenen bu iki kral, kutsal haçı kabul ettikten sonra hızla gerekli hazırlıkları yapmaya başladılar. Nihayet 1147 Mayıs ayında Alman Kralı Konrad yola çıtı ${ }^{47}$. Fransa Kralı Louis ise Haziran

\footnotetext{
${ }^{42}$ Kinnamos, Historia, 50.

${ }^{43}$ David Nicola, Askeri Tarih Dizisi II. Haçlı Seferi 1148, çev. L. Ece Sakor (İstanbul: Türkiye İş Bankası Yayınları, 2014), 42; Runciman, Haçlı Seferleri, 219.

${ }^{44}$ Ümit Kozcaz, "Denizli, Antalya ve Isparta Havalisindeki Haçlı Faaliyetleri”, (Isparta: Süleyman Demirel Üniversitesi, Sosyal Bilimler Enstitüsü, Yüksek Lisans Tezi, 2014), 16.

45 Bölgedeki Türk - Haçlı mücadelesi için bk. Michael Syrians, The Chronicle, ed. Robert Bedrosian (Long Branch 2013), 186 vd.; Smbat Sparapet, The Chronicle, ed. Robert Bedrosian (New Jersey: 2005), 48 vd.

${ }^{46}$ Runcıman, Haçlı Seferleri, 195; Altan, II. Haçlı Seferi, 8. II. Haçlı Seferinin sebepleri ile ilgili güzel bir değerlendirme için ayrıca bk. Nicole, II. Haçlı Seferi 1148, 5 - 12.

47 Jason T Roche, "Conrad III and The Second Crusade in The Byzantine Empire and Anatolia, 1147", (Fife: Universty of St. Andrews. Doktora Tezi, 2007) s.47
} 
sonlarında hareket etti. ${ }^{48}$

Haçlı ordularının Anadolu'ya kadarki seferleri bu makalenin konusu dışında olduğu için, II. Haçlı Seferinin bu kısmın değinmeyeceğiz. İstanbul'dan sonraki faaliyetlerini ise konumuz çerçevesinde ele alacağız. Alman İmparatoru Konrad'ın, Anadolu'ya geçtikten sonra Selçuklu başkenti Konya'ya, Eskişehir, Afyon Akşehir üzerinden ulaşmayı hedeflediğini görüyoruz. Bizans İmparatoru Manuel Kommenos'un, neredeyse tamamen Türklerin hâkimiyetinde olan bu araziden gitmesi durumunda ciddi zorluklar yaşayabileceği konusundaki uyarılarına rağmen Alman imparatoru, daha kısa olduğu için bu yolu tercihte 1 srarlı görünmekte idi. ${ }^{49}$ Manuel aslında Selçukluların hangi bölgelerde, ne kadar güçlü olduğunu biliyordu. Hatta 1144 seferinden dönerken Konya'ya gittiği bu yol yerine, muhtemelen daha güvenli olduğunu düşündüğü Isparta, Denizli güzergâhını kullanmayı tercih etmişti. Dolayısıyla Manuel, Eskişehir - Afyon güzergâhının kullanılması durumunda Haçlı birliklerinin ani bir Selçuklu hücumu karşısında hiçbir şanslarının olmadığını az çok tahmin ediyordu. ${ }^{50}$

İzmit'e ulaşan Konrad, burada ordusunu ikiye ayırdı. Ordunun savaşçı olmayan unsurunu ${ }^{51}$ birçok asille beraber Otto von Freising idaresinde, Laodikeia (Denizli) üzerinden Antalya limanına gönderdi. ${ }^{52}$ Görülen o ki; Konrad takip etmek istediği yolun zorluğu ve güvensizliği noktasında kısmen de olsa ikna olmuş ve savunma imkânları daha zayıf olan unsurları, daha güvenli olduğu söylenen Denizli - Antalya yolundan göndermiştir. ${ }^{53}$ Aslında II. Haçlı seferine katılan unsurların hatta Bizans imparatorunun en büyük yanılgısı bu idi. Hala Bizans hâkimiyetinde olan ve güvenli gördükleri bu yolun özellikle Denizli bölgesi Türkmenler tarafından çoktan kontrol altına alınmıştı.

Daha önce izah ettiğimiz gibi Ioannes döneminden beri bölgedeki Selçuklu-Bizans sınırı sürekli değişkenlik göstermekte idi. Manuel'in ilk başlardaki başarılarına rağmen sonu neredeyse hüsranla sonuçlanan 1144 seferinden sonra, Denizli ve çevresi çok hızlı bir şekilde Türkmenler tarafından ele geçirilmiş durumda idi. Her ne kadar bölgenin ovadaki iki büyük şehri Laodikeia ve Colosseia Bizans'ın elinde görünse de onların etrafını çeviren Çökelez ve Honaz dağları ile bu dağların arkaları tamamen Türkmenlerin hâkimiyetinde idi. Bizans ve Haçlılar bu durumu gözden kaçırdılar ve hala bölgenin Bizans'ın kontrolünde olduğu yanılgısına düştüler. Nitekim Otto von Freising yönetiminde, Denizli - Antalya güzergâhını tercih eden bu kol Denizli yakınlarında tamamen imha edilmiştir.

Konrad kendi emrindeki birliklerle (bunlar Alman ordusunun savaşçı vurucu gücü idi) önce İznik'e oradan da Eskişehir'e (Dorylaion) doğru yoluna devam etti ${ }^{54}$. Ancak yerli halkın Haçlı ordusundan nefreti sebebiyle gereken gıda desteğini vermemesi; hatta onları sattıkları gıda maddeleri ile zehirlemeye varacak kadar hasmane tutumu, Almanları çok zorlamaya başladı. Ayrıca Bizanslı rehberlerin de Haçlılara karşı bu olumsuz tavrı sürdürmesi ve onları zaman zaman yanlış yollara sürüklemeleri veya kritik yerlerde ordugâhtan ayrılmaları yüzünden bölge coğrafyasına tamamen

\footnotetext{
${ }^{48}$ Altan, II. Haçlı Seferi, 29-35.

${ }^{49}$ Altan, II. Haçlı Seferi, 60.

${ }^{50}$ Norwich, Bians-3, 105.

51 I. Haçlı seferinin hedefine ulaşması ve Kudüs'ün Haçlıların hâkimiyetine geçmesi sebebiyle, II. Haçlı seferinde Hac yapmak için Kudüs'e gitmek arzusuyla yola çıkan ve yüksek dini duygularla hareket eden sivil unsurlar da mevcuttu.

${ }^{52}$ Kesik, I. Mesut Dönemi, 82; Runcıman, Haçll Seferleri, 224; Nicole, II. Haçlı Seferi 1148, 43.

${ }^{53}$ Altan bu kuvvetlerin 7 - 8 Ocak 1148'de Kazıkbelinde ağır darbe yiyen Fransız kuvvetlerinden daha kalabalık olduğunu ifade etmektedir. Altan, II. Haçlı Seferi, 88.

${ }^{54}$ Alman imparatoru III. Konrad'ın Doryleon'da pusuya düşürülmesi ve ordunun büyük ölçüde imha edilmesi ile ilgili olarak teferruatlı bilgi için bk. Roche, Conrad III and Second Crusade, s.223.
} 
yabancı olan Almanlar, İznik’ten sonra gerçekten çok zor anlar yaşamaya başladılar. ${ }^{55}$ Nihayet 26 Ekim 1147 yılında Eskişehir yakınlarında bir akarsu kenarına yorgun, aç ve susuz olarak ulaşan Haçlılar, burada askeri disiplinden uzak bir tarzda dinlenmeye ve kamp kurmaya başladılar. Onları uzaktan takip eden Türkmenler için bu, bekledikleri fırsattı. Almanların üzerine ani ve şiddetli bir baskın düzenlediler ve ordunun büyük bölümünü burada imha ettiler. Ağırlıklarının ve ordusunun büyük bir kısmını kaybeden Konrad güç bela İznik kalesine ulaşıp oraya sığınarak hayatını kurtardı. ${ }^{56}$ $\mathrm{Bu}$ ağır yenilgiden sonra Konrad, seferin bundan sonraki kısmında son derece isteksiz davranmıştır. Fransa Kralı Louis'in etkisi ile bir şekilde Efes'e kadar gidebilen Alman İmparatoru, hastalığının kendisini zorlamaya başlaması ve Bizans imparatorunun da 1srarlı davetleri sebebiyle İstanbul'a geri dönmüştür. ${ }^{57}$

Almanlardan yaklaşık bir ay sonra yola çıkan Fransızların da İstanbul önlerinde çok fazla oyalanmasına izin verilmeden Bizans'ın yardımıyla Anadolu'ya geçirildi. ${ }^{58}$ Fransızların İstanbul önlerinde çok uzun süre kalmasını istemeyen Bizanslılar, Sultan Mesut'un, Anadolu'da büyük bir ordu hazırlığında olduğunu ve bu büyük ordunun hazırlanmasına firsat verilmeden bir an önce Anadolu'ya geçilmesi gerektiği konusunda tavsiyelerde bulundular. Ayrıca Konrad'ın, Anadolu'da parlak bir zafer kazandığı ve Fransızları büyük bir heyecanla beklediği söylentisini de yaymaya başladılar. ${ }^{59}$

Fransızlar İznik'e geldiklerinde, Konrad'ın başına gelenleri öğrendiler ve kesinlikle Akşehir Konya güzergâhını kullanma imkânlarının olmadığını anladılar. Bunun üzerine Louis, Efes Laodikeia - Antalya yolunu kullanmaya karar verdi. Antalya'dan da deniz yolu ile Kudüs'e gitmeyi planladı. 26 Ekim'deki ağır yenilginin etkisi ile Almanlar da yolculuğun bundan sonraki kısmında, Fransızlarla birlikte hareket etmek durumunda kaldılar.

Balıkesir yakınlarındaki Esserona geldiklerinde, iki kral arasında fikir ayrılığı baş gösterdi. Louis'in niyeti Balıkesir - Alaşehir (Phledelpheia) yolu ile Denizli’ye ulaşmaktı. Bu yol daha kısa olmakla beraber, Selçuklu sınırına çok yakındı ve bu yüzden endişe verici idi. Konrad ise sahil yolundan uzaklaşmadan gidilmesi ve Efes üzerinden Denizli'ye ulaşılması gerektiğini bu yolun daha uzun olmakla beraber daha güvenli olduğunu ifade etti. Belli ki Eskişehir'de uğradığı ağır yenilgi Konrad'1 oldukça tedbirli davranmaya itmişti. Louis de bu konuda ikna oldu ve Fransız - Alman birleşik ordusu Efes'e doğru yöneldi ${ }^{60} \mathrm{Bu}$ arada Efes'e uğramadan, daha içeriden Alaşehir üzerinden Laodikeia'ya gitme düşüncesi de tamamen iptal edilmemiş; az bir kuvvet bu yoldan giderek asıl ordudan önce Laodikeia'ya ulaşmıştır. ${ }^{61}$ Ancak birleşik haçlı ordusu çok güvenli olduğunu düşündüğü bu yolun daha Efes'e kadar olan kısmında bile çok ciddi sıkıntılar çekmeye başladı. ${ }^{62}$ Yukarıda belirttiğimiz gibi yerli halkın olumsuz tavrı ve coğrafyaya yabancı olmaktan kaynaklanan sıkıntılara ilaveten; 1147 - 1148 kışının çok sert geçmesi de Haçlı ordularının sıkıntısını daha da arttırmakta idi. ${ }^{63}$ Nitekim daha ordu Efes’te iken, yoğun yağışlardan kaynaklanan seller ve diğer mevsimler problemlerle mücadele etmeye başladılar.

\footnotetext{
55 Willermus Tyrensis, Haçlı Kroniği III (1143 - 1184), Tercüme ve Notlar Ergin Ayan, (İstanbul: Kronik Yayınları, 2019), 44; Gregory Abu'l-Farac (Bar Hebraeus), Abu'l-Farac Tarihi, çev. Ömer Rıza Doğrul, (Ankara: Türk Tarih Kurumu, 1999), 2/384; Nicola, II. Haçlı Seferi 1148, 42.

${ }^{56}$ Altan, II. Haçlı Seferi, 64.

${ }^{57}$ Kesik, I. Mesut Dönemi, 89.

${ }^{58}$ Fransızlar İstanbul önlerine geldiklerinde, Bizans için ciddi sıkıntılara sebep olmuşlardır. Zaman zaman iki hükümdarın arası açılmış; hatta Fransız ordusundan zaman zaman İstanbul'un işgali sesleri yükselmiştir.

${ }^{59}$ Norwich, Bizans-3, 104.

${ }^{60}$ Kozcaz, Haçlı Faaliyetleri, 12.

${ }^{61}$ Nicole, II. Haçlı Seferi 1148, 47.

${ }^{62}$ Odo de Deuil, Odo of Deuil De Profectione Ludovici VII In Orientem: The Journey of Louis VII the East, (New York: E-Book W.W. Norton, 1948), 105.

${ }^{63}$ Nicola, II. Haçlı Seferi 1148, 47.
} 


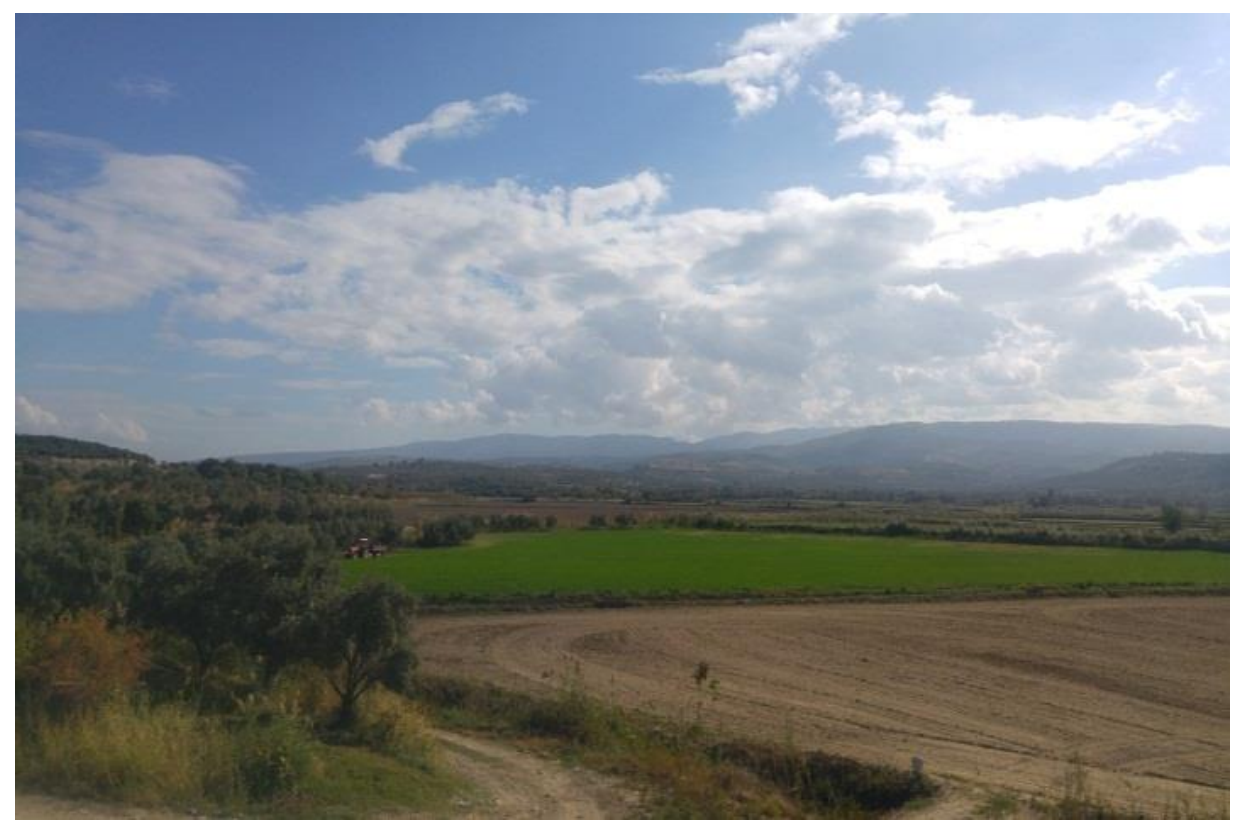

Resim 1. Kaynaklarda bahsi geçen, Türkmenlerin Fransızlara saldırmadan önce toplandıkları Antiocheia yakınlarındaki tepeler.

1147 Noel arifesini Efes yakınlarındaki Deversion Vadisinde ${ }^{64}$ geçiren Fransızlar, ${ }^{65}$ buradan itibaren Türkmenlerin tacizlerine de maruz kalmaya başladılar. ${ }^{66} \mathrm{Bu}$ şartlarda Efes’ten yürüyüşüne devam eden Louis, Denizli'ye yaklaşı 65 kilometre mesafedeki Antiocheia'da ${ }^{67}$ ilk ciddi sınavını verdi. Burada, Büyük Menderes nehrini geçmek zorunda olan Haçlı birliklerine karşı, onları Efes’ten beri takip eden Türkmenler, büyük bit saldırı gerçekleştirdi. Aslında Manuel'in, VII. Louis'e Efes'te bulunduğu sırada gönderdiği ve Türkler hakkında çok dikkatli olması; hatta kendine ait kalelere sığınabileceği tavsiyesinde bulunduğu mektubunda ${ }^{68}$ ne kadar haklı olduğu da anlaşılmış oldu. Her ne kadar Fransızlar, 1 Ocak 1148 'deki bu ilk ciddi saldırıyı zorda olsa püskürttü ise de ${ }^{69}$ bu saldırı bundan sonraki yaşayacakları sıkıntıların ilk habercisi gibiydi. ${ }^{70}$ Büyük ihtimalle burada savaşan unsurlar, daha geride Haçlıları bekleyen yoğun Türkmen birikiminin bölgedeki uç unsurları idi. ${ }^{71}$

${ }^{64}$ Muharrem Kesik, bu vadinin yerini tam tespit edemediğini ifade etmektedir. Kesik, I. Mesut Dönemi, 91. Efes-Antiocheia arasında bir birine benzeyen birçok vadinin bulunması Decervion vadisinin yerinin tespitini zorlaştıran en önemli faktörlerden birisidir.

${ }^{65}$ Odo de Doil, Odo of Deuil, 109.

${ }^{66}$ Altan, II. Haçlı Seferi, 83; Runciman, Haçlı Seferleri, 225.

${ }^{67}$ Burası ile ilgili olarak Willermus ayrıntılı tasvirler yapmaktadır. O eserinde bu bölgeyi kuğuların bol olduğu yeşil otlaklarla dolu bir yer olarak anlatır. Bu güzel coğrafya O’na; "Menderes kıyısında dalgalanan / Otların içindeki beyaz kuğu / Ölüm şarkısını söylerdi” mısralarını söyletecek kadar etkiler. Tyrensis, Haçlı Kroniği III, 49.

${ }^{68}$ Runcıman, Haçl Seferleri, 225; Altan, Haçl seferleri ve Anadolu, 44.

${ }^{69}$ Odo de Deuil, Odo of Deuil, 111.

${ }^{70}$ Gerek bazı haçlı kroniklerinde (bk. Tyrensis, Haçlı Kroniği III, 49.) gerekse çağdaş Bizans kaynaklarında (Khoniates, Historia, 45 vd.), Fransızların bu galibiyeti çok abartılı bir şekilde anlatılmıştır. Bu dönem kaynaklarında Türklere karşı alınan küçük galibiyetlerin bile aşırı abartılı anlatılma geleneği burada da karşımıza çıkmaktadır. Bu ifadelerin değerlendirilmesi ile ilgili olarak bk, Kesik, I. Mesut Dönemi, 92.

${ }^{71}$ Baykara Denizliye Dair Yazllarım, 47. 


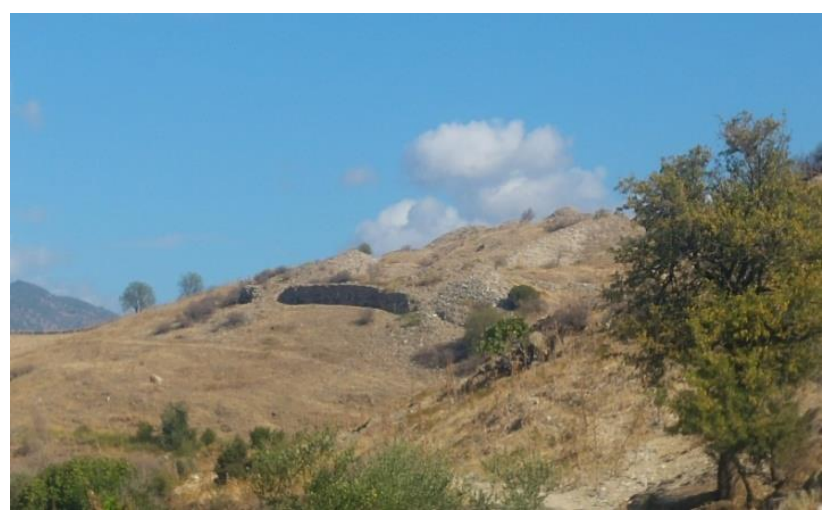

Resim 2. II. Haçlı Kuvvetlerinin Efes'ten Sonra Ŭ̆radıkları Antocheia Şehrinin Kalıntılarının Günümüzdeki Durumu

Antiocheia'da yaşadıkları ilk ciddi sıkıntıyı bir şekilde atlatan Haçlı kuvvetleri, Laodikeia'ya doğru yoluna devam etti. Artık, Bizans hâkimiyetinin nerdeyse tamamen lafta kaldığı topraklara girmişlerdi. ${ }^{72}$ Aslında Laodikeia, yukarıda da bahsettiğimiz gibi Ioannes Kommenos tarafından, Türklerin elinden alınıp tekrar Bizans topraklarına katılmıştı. Ancak, biraz sonra anlatacaklarımızdan da anlaşılacağı gibi burada Bizans'ın siyasi bir varlığından söz etmek nerede ise imkânsızdır. Bölge tamamen Türkmenlerin kontrolü altında idi. Bundan sonra Haçlılar, Türklerin saldırılarına karşı koyabildikleri ölçüde yol emniyetini temin edebileceklerdi.

1 Ocak'ta Antiocheia'dan hareket eden Fransız kuvvetleri, yaklaşık 65 kilometrelik yolu 3 günde kat edip $^{73} 4$ Ocak'ta Laodikeia'ya ulaştılar. ${ }^{74} \mathrm{Ne}$ var ki, Louis büyük umutlarla geldiği Laodikeia'da, tam bir hayal kırıklığına uğradı. Haçlılarla ilgili Anadolu'daki olumsuz algı, Laodikeia halkını da etkilemiş ve halk şehri boşaltarak çevredeki dağlara çekilmiştir.

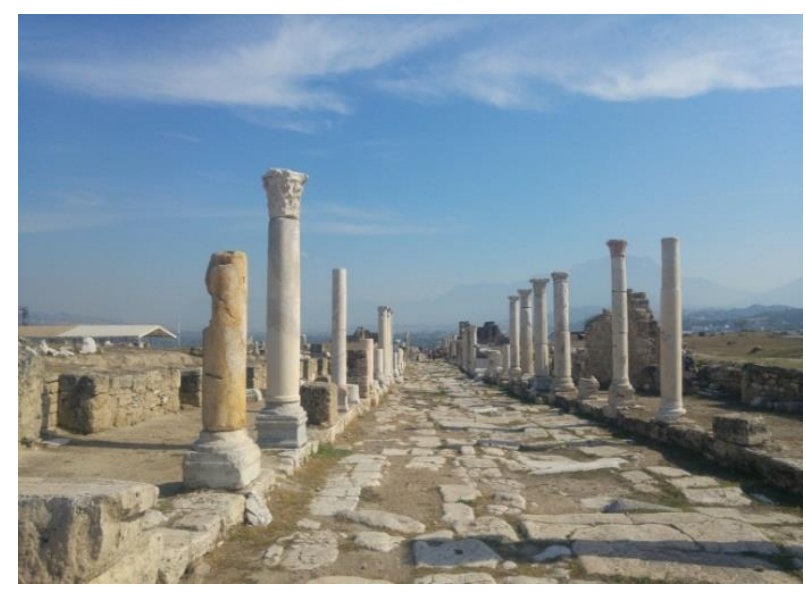

Resim 3. Haçlıların büyük bir umutla geldiği ancak halkın şehri boşaltması sebebiyle büyük hayal kırıklı̆̆ına uğradıkları Laodikeia antik şehrinin günümüzdeki kalıntıları

\footnotetext{
${ }^{72}$ Nicole, II. Haçll Seferi 1148, 50.

${ }^{73}$ Odo de Deuil, Odo of Deuil, 113.

${ }^{74}$ Bazı kaynaklarda Haçlıların Laodikeia’ya gelişi 4 Ocak 1148 olarak gösterilmektedir. Kesik, I. Mesut Dönemi, s.93; Baykara, Selçuklular ve Beylikler Çağında Denizli, 39; Runcıman, Haçlı Seferleri, 225. Bunun yanında bu tarihi 3 Ocak olarak belirten kaynaklar da vardır. Tyrensis, Haçlı Kroniği III, 49; Nicolle, II. Haçlı Seferi $1148,50$.
} 
$\mathrm{Bu}$ dağlar çok büyük ihtimalle şehrin kuzey ve kuzeydoğusunda uzanan Çökelez Dağıdır. Çünkü Karcı Dağı, Laodikeia halkı için o dönemin şartlarında oldukça uzak kalmaktadır. Doğu ve güneydoğuda bulunan Honaz dağının ise Türkmenler tarafından tutulmuş olması ve Haçlıların mecburi yol güzergâhında bulunması sebebiyle Laodikeia halkının bu iki dağa sığınma ihtimali çok düşüktür. Her ne kadar Tuncer Baykara, Laodikeia'ya halkının güneydeki dağlara sığındığını ifade ediyorsa $\mathrm{da}^{75}$ biz, yukarıda açıkladığımız gerekçelere bağlı olarak bu dağın Laodikeia’ya daha yakın olan Çökelez Dağı olduğu kanaatindeyiz. Dolayısıyla şehirlerini boşaltan Laodikeia halkın sığındığı dağ, güney yamaçlarında Pamukkale'yi de barındıran Çökelez dağıdır. Ayrıca burada bulunan ve bu yıllarda harbeye dönüşmüş olan Hiereapolis şehrinin kalıntıları da halkın barınma ve gizlenmesinde bir tercih sebebi olabilmiştir.

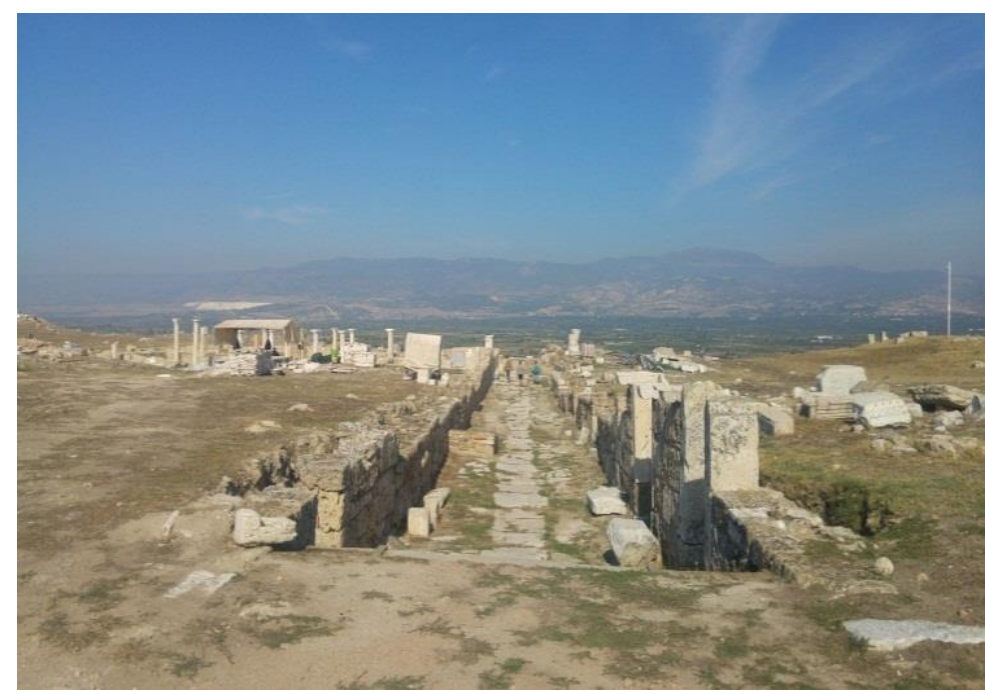

Resim 4. Haçlı Kuvvetleri Laodikeıa'ya geldiğinde halkın şehri terk ederek gizlendiği Çökelez Dağının Laodikeia'dan görünüşü

Kral Louis, din adamlarını ve asillerini toplayarak bu duruma bir çare bulmak istedi. Çünkü Laodikeia halkından temin edeceği lojistik malzemeye çok fazla ihtiyacı vardı. Yapılan toplantıda din adamlarının patika yollardan gidip dağda saklanan halkı bulmaları ve kendilerine zarar verilmeyeceğine dair teminatlar verilip şehre geri dönmelerinin sağlanması kararı alandı. ${ }^{76}$ Ancak bu tedbir etkili olmadı ve halk şehre dönmedi. ${ }^{77}$ Hatta bazı Haçlı kronikleri Leodikeia'nın boşaltılması ve Kral Louis'in askerlerinin gerekli lojistik desteği alamamaları olayını Bizans halkının Haçlılara bir ihaneti olarak algılamışlardır. ${ }^{78} \mathrm{Bu}$ arada, II. Haçlı Seferi ile ilgili bilgi veren önemli kaynaklardan birisi olan Willermus, Leodikeia'nın boşaltılmasından hiç bahsetmediği gibi, Haçlıların bu şehirden birkaç günlük yiyecek alıp yola devam ettiklerinden bahseder. ${ }^{79}$ Buna karşın, yerli ahalinin şehirdeki mevcut erzakları da yanlarında götürdükleri hatta götüremediklerini yaktıklarını ifade eden kaynaklar

\footnotetext{
${ }_{75}^{75}$ Baykara, Selçuklular ve Beylikler Çă̆ında Denizli, 39.

${ }^{76} \mathrm{Bu}$ veri de Laodikeia halkının sığındığı dağın Çökelez Dağı olma ihtimalini güçlendirmektedir. Çünkü din adamlarının yaya olarak patikalardan halkın saklandığı mağaralara ulaşabilmeleri bizim bu konudaki görüşümüzü destekler mahiyettedir.

${ }^{77}$ Odo de Deuil, Odo of Deuil, 115.

${ }^{78}$ Nicole, II. Haçll Seferi 1148, 50; Altan, II. Haçlı Seferi, 85.

${ }^{79}$ Tyrensis, Haçlı Kroniği III, 49.
} 
da vardır. ${ }^{80}$

Böylesine hayalete dönmüş bir Laodikeia ile karşılaşmaları Fransızların ve kralları Louis'in moralini çok bozdu. Halkın bu tavrında, Haçlılarla işbirliği yapıp; Türklere karşı hasmane bir tutum sergiliyor olmak istememe düşüncesi etkili olmuştur. Zira Haçlılar bu bölgeden çekip gittikten sonra burada ki halk, tekrar Türkmen unsurlarla yüz yüze kalacaktır. Bu bölgede Türk hâkimiyeti, Bizans hâkimiyetinin çok önündedir. Özellikle Efes'ten ayrıldıktan sonra bu durumu hissetmeye başlayan Haçlılar, kıyı Ege'den iç bölgelere doğru ilerledikçe azalan Bizans hâkimiyetini bizzat müşahede etmişlerdir.

Mevcut şartlar altında Louis'in, Laodikeia'da daha fazla kalmasının bir anlamı kalmamıştır. Çünkü bu bölgeden lojistik bir destek temin etme ihtimalinin olmadığı anlaşılmıştır. Artık Louis'in önünde tek bir seçenek olduğu görüldü. $\mathrm{O}$ da, bir an önce önündeki en büyük engellerden birisi olan Honaz dağını aşıp, dağın arkasındaki yeni kaynaklara ulaşmak ve ihtiyaçlarını orada gidermenin yollarını araştırmaktır.

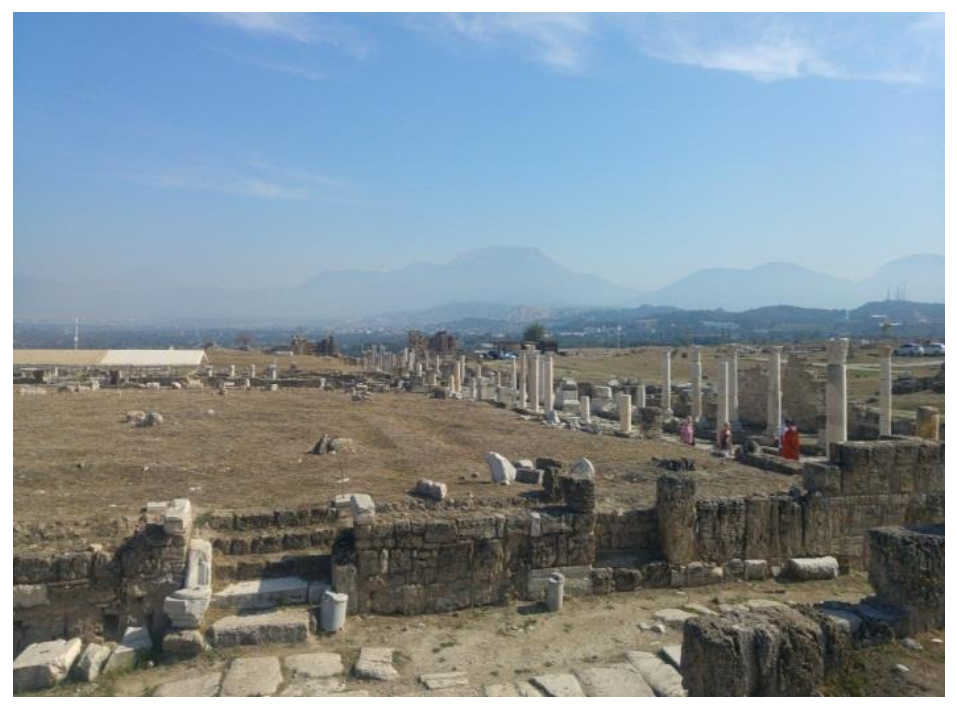

Resim 5. Haçlı birliklerinin Laodikeia'dan sonra Antalya'ya gidebilmek için geçmek zorunda olduğu ve pusuya düşerek çok büyük kayıplar verdiği Honaz Dağının Laodikeia'dan görünüşü

Louis, 3 günlük bir oyalanmadan sonra Laodikeia'dan ayrılıp, Honaz dağını aşarak daha güvenli olduğunu düşündüğü topraklara ulaşabilmek için yola çıktı. Laodikeia'dan umduğu lojistik desteği sağlayamayan ve Türk tacizleri sebebiyle zaten disiplinsiz ilerleyen Haçlılar, Honaz Dağındaki Kazıkbeli geçidini aşmak zorunda idiler. Geçit çok dar olduğu ve Türkler tarafindan tamamen tutulduğu için, bu geçit boyunca her hangi bir konaklama imkânları da yoktu. Onun için Louis, bir gün boyunca ilerleyip geçide yakın bir yerde geceyi geçirmek; ertesi günde bu geçidi aşıp, dağın arkasındaki düzlüklerin birine ulaşmak düşüncesinde idi. ${ }^{81}$ Bu düşüncelerle Haçlı ordusu 7 Ocak 1148 günü Laodikeia'dan hareket etti. ${ }^{82}$

\footnotetext{
${ }^{80}$ Fahri Akçakoca Akça, Laodiceia (Yunanlılardan - Selçukluların Inkırazına Kadar), (Denizli 1937), 31.

${ }^{81}$ Altan, II. Haçlı Seferi, 86.

${ }^{82}$ Haçlı ordusunun Honaz Dağını aşmak için kullanmayı düşündüğü güzergâh günümüzde de kullanılan batı yamacı geçidi değil, yeni yol yapılıncaya kadar bölge halkı tarafından ulaşımda kullanılmaya devam eden doğu yamacındaki geçittir. Baykara, Denizliye Dair Yazılarım, 49.
} 
Zorluklar yola çıktıktan kısa süre sonra ortaya çıkmaya başladı. Haçlı askerleri mevsime bağlı olarak başlayan kötü hava koşulları ve Laodikeia'da umduğu kaynaklara ulaşamadıkları için, açlıkla mücadele etmek zorunda kalıyorlardı. Bu arada kısa bir süre önce Konrad tarafından bölgeye gönderilen ve aynı yerlerden geçmeye çalışırken Türkmenler tarafından bütünüyle imha edilen Almanların cesetlerini gören askerlerin ${ }^{83}$ çöken maneviyatları de bir başka zorluk idi. ${ }^{84} \mathrm{Bu}$ zorluklarla mücadele eden Haçlılar yavaş yavaş Honaz dağında ilerlemeye başladılar ve dağın en riskli noktalarından birisi olan Kazıkbeli geçidinin önlerine geldiler.

Louis, bu zorlu geçidi en emniyetli şekilde aşabilmek için planlarını yaptı ve kendine göre tedbirlerini aldı. Ordusunu üç gruba ayıran Fransa Kralı, öncü birliklerin başına dayısı Amadeus de Savoyen ile Geoffroi de Rancon adında bir asili komutan olarak tayin etti ${ }^{85}$ Bu birliğin içinde Kraliçe Elanor da bulunmakta idi. Birkaç asilini ise ordunun orta kısmında bulunan hacılar ve yayaları korumakla görevlendirmişti. Kendisi ise ordudaki asillerin çoğu ile beraber arţ̧ı kola komuta edip muhtemelen ordunun arkasını toplamayı planlamıştı. ${ }^{86}$

Bu düzenle 7 Ocak günü, ${ }^{87}$ Haçlı öncü birlikleri Kazıkbeli geçidini aşmak için yola koyuldu. Kraliçe Elenor'un da içinde olduğu ve kalabalık savaşçı unsurlardan oluşan bu kol, kralın sancağı ile beraber ordunun önünden yürümeye başladı. Tahmin edilenden çok daha kısa sürede, öğleye doğru geçidin ağzına ulaştı. Muhtemelen ordunun genel durumunu bulundukları hâkim bölgelerden gözleyen Türkmenler, kalabalık savaşçı unsurlardan oluşan bu kola fazla müdahale etmedi. Böylece bu unsurlar hızlı bir ilerleyişle geçide geldiler. Louis'in planına göre bu birlikler burada kamp kuracak ve ordunun tamamı burada toplandıktan sonra ertesi gün önlerindeki zorlu geçit aşılacaktı. Ancak öncü birliğin komutanları az bir mesafe kat ettiklerini düşünüp boşuna burada oyalanıp zaman kaybetmektense günün kalan kısmında da yürüyüşe devam edip, geçidin ilerisinde uygun bir kamp yeri bulmanın daha doğru olacağını düşündüler. Bu arada Kraliçe Elanor'un da bu konuda ısrar ettiği ve bir an önce daha emniyetli olduğunu düşündüğü geçidin ilerisindeki düzlüğe ulaşmak için öncü birliklerin ilerlemesini teşvik ettiği ifade edilmektedir. ${ }^{88}$ Böylece Louis'in harekât planının dışına çıkan öncü birlikler, kendileri kadar hızlı hareket etme imkânı olmayan ordunun geriden gelen unsurlarını beklemeden geçidi geçmeye karar verdiler. Geçidi bir an önce aşmak isteyen öncü birlikler muhtemelen daha hızlı hareket etmeye başladılar. Bu birlikler her geçen saat, arkadan gelen ve daha yavaş hareket kabiliyetine sahip unsurlarla aralarındaki mesafeyi açmaya başladılar. Türkmenler de büyük ihtimalle tasarladıkları savaş planı çerçevesinde öncü birliklere müdahale etmedi ve bir an önce onların tepeyi aşmasını istedi.

Gerçekten de Türkmenlerin istediği gerçekleşti ve öncü birlikler arkadan gelen, çoğu yaya olan ve Kudüs'e hacı olmak için giden sivillerden oluşan ortadaki birliklerle mesafeyi iyice açtı. Bu arada ortadaki birlikler de öncü birliklerin geçidi geçip tepeyi aştığını görünce yola devam etmeye karar verdi ve Louis'in planı tamamen yok oldu. Ancak bu vahim hata Haçlılar için çok pahalıya mal oldu. Geçitte ilerledikçe yaya ve arabalardan oluşan bu birlik için yol iyice zorlaşmaya başladı. Yük arabaları uçurumlardan yuvarlanıyor, yerinden kopan kayalar insanların ve hayvanların üstüne düşüyordu. Bu kayalar, yuvarlanan bir araba veya hayvanın kopardığı kayalardı ve daha aşağıda yukarı tırmanmaya çalışan kendi arkadaşlarını öldürüyordu. Ayrıca pusuya yatmış Türkmenler

${ }^{83}$ Odo de Deuil, Odo of Deuil, 115.

${ }^{84}$ Runcıman, Haçlı Seferleri, 226; Nicola, II. Haçlı Seferi 1148, 50; Altan, II. Haçlı Seferi, 86.

${ }^{85}$ Odo de Deuil, Odo of Deuil, 115.

${ }^{86}$ Nicola, II. Haçlı Seferi 1148, 50.

${ }^{87}$ David Nicola bu tarihi 8 Ocak 1148 olarak vermektedir. Bk. Nicola, II. Haçlı Seferi 1148, 50.

${ }^{88}$ Kraliçe Elanor'un, bu zor şartlardaki durumu şu şekilde tasvir edilmiştir. "Kraliçe ve nedimeleri mahfilleri içinde soğuktan titreyerek, bir daha böyle güç bir seyahate çıkmamaya yeminler ediyorlardı." Runcıman, Haçlı Seferleri, 226. 
tarafından bu askerlerin üzerine yoğun şekilde ok, taş ve kaya atılmaya başlandı Artık ortadaki birlik için bu yolculuk tam bir kâbusa dönüşmüştü. Ölen askerler ve hayvanların cesetleri, ya da atacağı yanlış bir adımla uçuruma yuvarlanma endişesi yahut bir Türkmen okuna hedef olma korkusu ile yerinde yığılıp kalan insan kalabalıkları sebebiyle bu birlik hiç hareket edemez hale geldi. Türkmenlerin muhtemelen en başından beri beklediği firsat bu idi. Bunun için öncü birliklere müdahale etmemiş onların hızlı ilerleyişlerini sürdürerek ortadaki birliklerle arasını açmaya müsaade etmişlerdi. Tepeyi aşan öncü birlikler olup bitenden habersizdi ve ortadaki birlikle bıraktıkları geniş boşluk Türkmenler tarafından doldurulmuştu.

Haçlılar için bu vahim tablonun oluşmasında, Türkmenlerin akıllıca planladıkları ve başarı ile uyguladıkları pusu planı kadar, coğrafi faktörlerde etkili olmuş olmalıdır. Zira bölgenin kendine özgü ilginç bir mikro klimatik özelliği vardır. Günümüzde bile kış aylarında Denizli merkezde kısmen 1lık ve güneşli bir gün varken, Honaz dağına doğru 15 - 20 kilometre tırmandıktan sonra aniden bastıran bir sis veya tipi ile karşılaşılabilir. Dolayısıyla Haçlıların böylesine olumsuz bir iklimsel durumla karşılaşmış olma ihtimali de yüksektir. Aslında Haçlılar, bölgeye yabancı olmanın ve iklimsel özelliklerin sıkıntılarını Efes'ten ayrıldıkları andan beri yaşıyorlardı. ${ }^{89}$

Türkmenler artık dar bir alanda sıkıştırdıkları Haçlı ordusunun yayalar ve ağırlıklardan oluşan ve yaklaşık 10 kilometre uzunluğu bulunan bu kısmını hızla imha etmeye başladılar. Pusuya düşürdükleri bu birliklere var güçleri ile saldırıyor, kayaların ve ağaçların üzerinden onları ok yağmuruna tutuyorlardı. Arkadan gelen Kral Louis, geçide yaklaştıkça ordusunun başına gelenleri anlamaya başladı. Geçide girdiği andan itibaren ordusunun pusuya düştüğünü gördü ve kendisini tam bir ölüm kalım mücadelesinin içinde buldu. Louis, bu savaş sırasında 40 civarındaki özel maiyetinin tamamını kaybetti. Kendisi ise ağaç köklerine tutunup, bir kayalığa tırmanarak canını zor kurtarabildi. Türkmenler kısa süre önce daha güçlü bir orduyu imha etmiş olmanın (Konrad'ın bölgeye gönderdiği Otto von Frreissing idaresindeki Alman birlikleri) öz güveni ile saldırı ve baskılarını iyice arttırdı. ${ }^{90}$ Ancak karanlığın çökmeye başlaması üzerine sürpriz bir saldırıya uğramamak istemeyen Türkmenler savaş alanından yavaş yavaş ayrılmaya başladılar. ${ }^{91}$

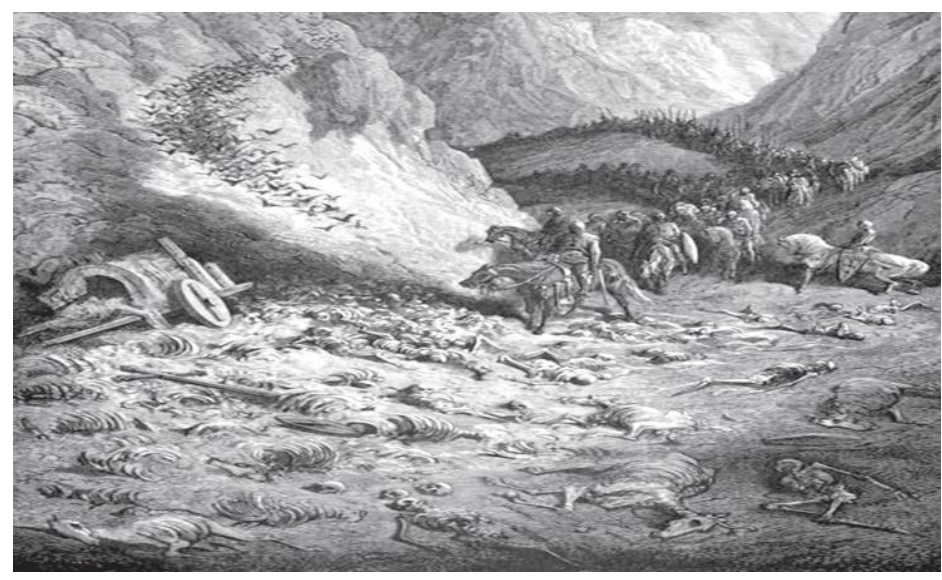

Resim 6. Freshing komutasında Denizli'ye gelen ve Honaz Dağında imha edilen Alman kuvvetlerinin cesetleri arasinda ilerleyen Fransiz birlikleri

\footnotetext{
${ }^{89}$ Nicola, II. Haçlı Seferi 1148, 47.

${ }^{90}$ Tyrensis, Haçll Kroniği III, 50.

${ }^{91}$ Odo de Deuil, Odo of Deuil, 117.
} 
Bu pusudan kurtulabilenler, karanlığın çökmesinden istifade ederek bölgeden uzaklaşabilenler oldu. Kral Louis de akşam karanlığından faydalanarak güç bela tepeye ulaşabildi. Burada temin ettiği bir at ile önden giden ve kamp yerlerinde arkadan gelenleri bekleyen, öncü birliklerin yanına ulaşmayı başardı. Hatta yolda kralın pusuya düştüğünü bir şekilde öğrenen ve kamptan ayrılıp kendisinin yardımına gelen şövalyelere rastladı. Nihayet Louis, bitkin ve perişan bir vaziyette gece yarısı öncü birliklerin oluşturdukları kamp yerine ulaşabildi.

Dönemin çağdaşı ve en önemli kaynaklarından birisi olan Willermus Tyrensis, dindar bir Hristiyan olarak, yazdığı eserinde Haçlıların uğradığı bu ağır yenilgiyi şöyle tasvir etmektedir: “ ... Uzun bir süre savaştıktan sonra Türkler sonunda bizim yarı günahlılara karşı üstünlüğ̈̈ ele geçirdi. Haçlıların bir kısmı savaşta ölürken çoğu da tutsak oldu ve bütün ordudan kü̧̈ük bir miktar kaldı. O gün askeri başarılarıyla ünlü soylu yüce birçok adam öldü. Ordunun büyük kahramanlarından Barannes Kontu Galcherus ve Montiay Evrardus von Bretol, Iterus von Magnac ve adlarl semaya yazllası bizim bilmediğimiz daha niceleri bunların arasındaydı. Bize bela getiren o gün, inançsızların önünde titrediği Frankların şan ve şerefleri yok oldu. Ayrlca Franklar, Tanrı tanımaz ulusların alay konusu haline geldiler. Neden ey İsa !... Sana sadakatle bă̆ll, senin ayak izlerini öpen ve kutsadı̆̆ın topraklarda ibadet etmek isteyen insanların, sana düşman olanların elleriyle imha edilmesine izin verdin?..." Dımışk'ta (Şam) meyve veremeden soldular" cümlesi ile dile getirmiştir. ${ }^{93}$

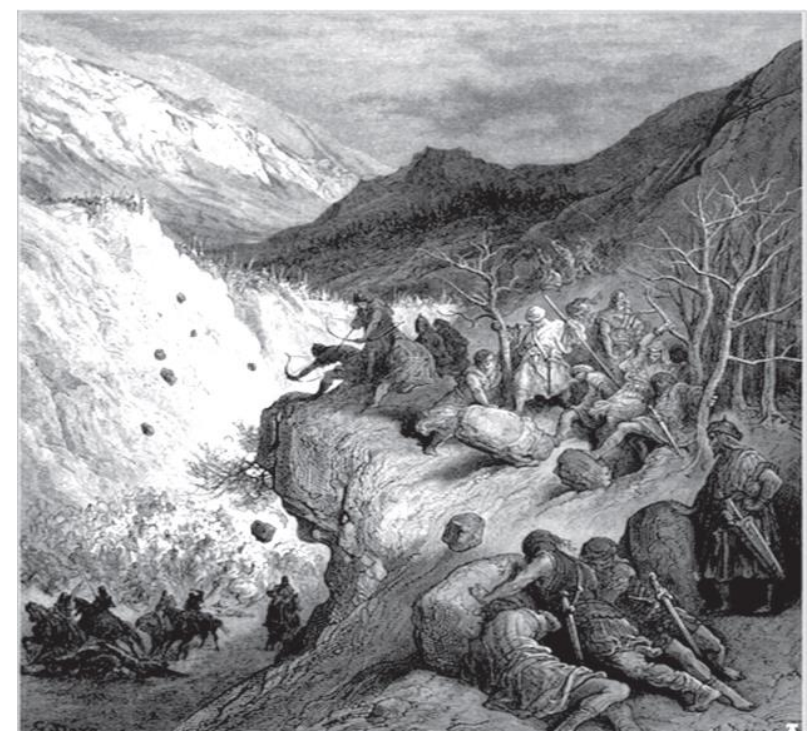

Resim 7. Haçlıların Kazıkbeli’nde pusuya düşmeleri

$\mathrm{Bu}$ ağır yenilgiden sonra Louis gibi, geçitteki pusudan kurtulabilenler gecenin karanlığından istifade ile birer ikişer kamp yerine ulaşmaya başladılar. Hemen herkes bu felaketin öncü birliklerin komutanı Geoffroi'nin kralın palanına uymayıp kendi başına verdiği karar sebebiyle yaşandığının farkında idi. Bu yüzden O'na olan kızgınlık hat safhada idi. Hatta Geoffri'nin idam edilmesini isteyenler bile vardı. Ancak bir başka gerçek te, Geoffri ile beraber aynı sorumluluğa sahip ve suça ortak Amadeus'un Kralın dayısı olmasıdır. Eğer bir idam gerçekleşecekse her ikisinin de idam edilmesi gerekirdi. Louis dayısını idam etmeyip bağışlamak zorunda olduğu için Geoffriyi de

\footnotetext{
${ }^{92}$ Tyrensis, Haçlı Kroniği III, 51.

${ }^{93}$ Odo de Deuil, Odo of Deuil, 119.
} 
bağışlamak durumunda kaldı. Sadece ceza olarak O’nu ülkesine geri gönderdi. ${ }^{94}$

8 Ocak 1148 günü uğradıkları büyük baskının yaralarını kısmen saran Haçlılar tekrar yola koyuldular. Zira Antalya'ya bir an önce ulaşmak ve kendileri için her bölgesi felaket tehlikeleri ile dolu Türk hâkimiyetindeki bu topraklardan en kısa sürede kurtulmak zorunda idiler. Ancak yolun bundan sonraki kısmı da oldukça zorlu ve çetin geçti. Türkmen saldırıları Honaz'daki kadar yoğun olmasa da Antalya'ya kadar hiç bitmedi. Bu arada Bizanslı yerli halk ta Türkmenlerle iş birliği yaparak Haçlıların geçeceği yollardaki yiyecek kaynaklarını ve otlakları imha ederek durumu Fransızlar için iyice berbat hale getirdiler. ${ }^{95}$ Nihayet çok büyük zorluklar çeken ve ciddi kayıplar veren Haçlilar, perişan bir şekilde 20 Ocak $1148^{\prime}$ de Antalya'ya ulaştılar. ${ }^{96}$

\section{SONUÇ}

Denizli ve çevresi, tarihin en eski dönemlerinden beri bir ilgi odağ 1 ve çekim merkezi olmuştur. Nitekim bölgede birçok önemli antik dönem şehirleri ve höyüklerin mevcudiyeti bunun en güzel göstergesidir.

Denizli bu özellikleri ile Türklerin, Anadolu'ya gelmeye başladıkları ilk dönemlerden itibaren Türkmen unsurların da ilgisini çekmiştir. Bunun için kaynaklarda daha 1100'lerin başlarından itibaren bölgedeki Türk varlığından bahsedilmektedir. Bölge hızlı bir şekilde Selçuklu egemenliğine katılmaya çalışılmış bu konuda oldukça önemli mücadele verilmiştir. Aynı şekilde Bizans ta kendisi için stratejik bir öneme sahip olan bu bölgeyi elinde tutabilmek için yoğun bir çaba harcamıştır. Özellikle 11. yüzyılda bölgenin en önemli merkezi konumunda olan Laodikeia, bu mücadelenin en ağırlıklı kısmını teşkil etmiştir. Laodikeia'nın Selçuklu hâkimiyetine geçiş sürecinin tespiti, bu bölgedeki Türk hâkimiyetinin kesinlik kazanması ile ilgili çalışmalara önemli bir ışık tutacaktır.

Bizans, Denizli ve çevresindeki Türkmen varlığının hâkimiyetini kırma noktasında çok ta başarılı olamamıştır. Zaman zaman siyasi olarak bölgede hâkimiyet sahasını genişletmeye çalıştı ise de; özellikle Türkmenler üzerinde bu gayretlerin fazlaca bir etkisi olmamıştır. Nitekim Manuel Kommenos, 1146 y1lında Konya'ya kadar uzanan seferinden dönerken Denizli’nin hemen kuzeyindeki Türkmen varlığını bizzat kendisi müşahede etmiştir.

Bu yıllarda Denizli ve çevresinde yaşanan en önemli gelişmelerden birisi de II. Haçlı seferidir. Seferin ilk grubunu teşkil eden Almanların Eskişehir, Afyon, Akşehir, Konya üzerinden Çukurova ve Kudüs'e ulaşma fikri daha yolun başında Eskişehir'de aldıkları ağır yenilgi ile akamete uğramıştır. Bu gelişme üzerine Almanların hemen arkasından Anadolu'ya gelen Fransız kuvvetleri mecburen güzergâhlarını değiştirmek zorunda kalmışlardır. Fransızlar, daha güvenli olduğunu düşündüğü Balıkesir, Efes, Denizli, Antalya yolundan Anadolu'yu aşmayı tasarlamışlardır. Antalya'ya ulaştıktan sonrada buradan deniz yolu ile Kudüs'e gitmeyi arzulamışlardır. Ortaçağ Denizli Tarihinin tam anlaşılabilmesi için, Haçlı seferlerinin ve bilhassa II. Haçlı Seferinin bölgenin siyasi ve kültürel tarihinde oynadığı rolün tespiti çok önem arz etmektedir. Biz bu makalemizde siyasi yapıyı kısmen ortaya koymaya çalıştık. Ancak, seferler sonrasında bölgedeki siyasi değişim ayrıca bir inceleme konusudur. Yine II. Haçlı seferinin bölgenin sosyal ve kültürel dokusunda bir iz bırakıp bırakmadığı meselesi de üzerinde durulması gereken bir konudur.

Ancak VII. Louis idaresindeki Fransız Haçlı kuvvetleri Efes'ten sonraki yolculuklarında bölgedeki güçlü Türkmen varlığını hissetmeye başlamışlardır. Haçlılar bir taraftan Türkmen saldırıları ile uğraşırken diğer taraftan lojistik destek yetersizliği sebebiyle ciddi bir açlık problemi ile karşı

\footnotetext{
${ }^{94}$ Altan, II. Haçlı Seferi, 90.

${ }^{95}$ Nicole, II. Haçlı Seferi 1148, 50.

${ }^{96}$ Altan, II. Haçlı Seferi, 93.
} 
karşıya kalmışlardır. Büyük bir umutla Laodikeia'ya ulaşmayı arzulayan Haçlılar burada tam bir hayal kırıklığı yaşamışlardır. Çünkü şehrin Bizanslı halkı Laodikeia'yı boşaltmış ve Çökelez Dağına sığınmıştır. Bu konuda bundan sonra yapılacak çalışmalarda daha netlik kazanacaktır kanaatindeyim.

Burada gereken lojistik desteği sağlayamayan Louis, bir an önce Honaz Dağını aşıp, daha güvenli olduğunu düşündüğü Korkuteli üzerinden Antalya'ya ulaşmak için yola çıkmıştır. Efes'ten beri Haçlıları takip eden Türkmenler, Haçlılara Honaz Dağında nihai darbeyi vurmak için hazırlık yapmışlardı. 7 Ocak 1148 günü Honaz Dağında pusuya düşen Fransız birlikleri çok ağır kayıplar verdiler. Kralları Louis bile hayatını güçlükle kurtarabildi. Olayın görgü şahidi Odo de Deuil'in dediği gibi “Fransa'nın fidanları Dımışk'ta çiçek açmadan Anadolu'da solmuştu".

Kral Louis ve yanındaki kurmaylarının çoğu da Efes - Antalya arasında yaşadıkları büyük sıkıntılardan oldukça etkilendiler. Honaz dağında kuvvetlerinin büyük bir kısmını kaybeden Louis, Antalya üzerinden Kudüs'e ulaşmayı başardı. Ancak Kudüs'te kayda değer hiçbir faaliyette bulunamadan ülkesine dönmek durumunda kaldı. Urfa'nın Nureddin Zengi tarafından ele geçirilmesi üzerine büyük bir heyecan ile başlayan II. Haçlı seferinin, Almanların öncülügündeki ilk grubu Eskişehir'de, Fransızların öncülüğündeki ikinci grubu ise Honaz Dağında nihayet bulmuş oldu.

Tabii ki bu seferin Denizli'de aldığı ağır darbeden sonra etkinliğini kaybetmesi ve Kudüs'e çok az sayıda kişinin ulaşabilmesi, Ortadoğu ve Kudüs tarihi açısından da önemli sonuçlar doğurmuştur. Bir anlamda buraların yeni bir Haçlı istilasına uğramasının önü Honaz Dağındaki baskınla kesilmiş oldu.

Funding / Finansman: This research received no external funding. / Bu araştırma herhangi bir diş fon almamıştır.

Conflicts of Interest / Çıkar Çatışması: The author declare no conflict of interest. / Yazar, herhangi bir çıkar çatışması olmadığını beyan eder.

\section{KAYNAKÇA}

Abay, E - Dedeoğlu, F. "Beyce Sultan 2007 - 2008 Yılları Kazı Çalışmaları Ön Raporu”. Arkeoloji Dergisi. XIII/1. 2009. 53-79.

Abu'l-Farac, Gregory. (Bar Hebraeus). Abu'l-Farac Tarihi II. çev. Ömer Riza Doğrul. Ankara: Türk Tarih Kurumu 1999.

Akça Akçakoca, Fahri. Laodikeia (Yunanlılardan - Selçukluların İnkırazına Kadar). Denizli 1937.

Altan, Ebru. II. Haçlı Seferi (1147 - 1148). Ankara: Türk Tarih Kurumu 2003.

Altan, Ebru. "Haçlı Seferleri ve Anadolu (1097 - 1190): Türkiye Selçukluları Tarihinde Haçlı Seferlerinin Yeri ve Önemi". USAD. Bahar 2020/12. (2020). 35-50.

Anonim Haçlı Tarihi. yay. haz. Ergin Ayan. İstanbul: Selenge Yayınları 2013.

Ayönü, Yusuf. Selçuklu - Bizans Münasebetleri (1116-1308). İzmir: Ege Üniversitesi, Sosyal Bilimler Enstitüsü, Doktora Tezi 2007.

Baykara, Tuncer. Denizli’ye Dair Yazılarım. Denizli: Denizli Büyükşehir Belediyesi Yayınları 2019.

Baykara, Tuncer. Selçuklular ve Beylikler Çağında Denizli 1070 - 1520. İstanbul: IQ Yayınları 2007.

Cahen, Claude. Osmanlılardan Önce Anadolu. çev. Erol Üyepazarcı. İstanbul: Tarih Vakfı Yurt Yayınları 2000.

Dedeoğlu, Fulya vd. "Ekşi Höyük 2015 Kazı Çalışmaları". 38. Kazı Çalışmaları Toplantısı (23 - 27 Mayıs 2016 Edirne) II. Edirne 2017. 273-286.

Demirkent Işın. "Haçlı Seferi Düşüncesinin Doğuşu ve Hedefleri”. İÜEFTD. 35. (1994). 65-78.

Deuil, Odo de. Odo of Deuil De Profectione Ludovici VII In Orientem: The Journey of Louis VII the East. New York E-Book W.W. Norton 1948.

Diehl, Charles. Bizans Imparatorluğu Tarihi. çev. Selim Sezer. İstanbul: İnkılap Yayınevi 2018.

Düzgün, Şaban Ali. “ İki Dünyanın Karşılaşması: Müslüman ve Latin Batı Dünyası Arasında Haçlı Seferleri Dönemindeki İlişkiler". İslami Araştırmalar Dergisi. 14/3-4. (2001). 349-360.

Kesik, Muharrem. Türkiye Selçuklu Devleti Tarihi Sultan I. Mesutd Devri (1116-1155). Ankara: Türk Tarih Kurumu 2003.

Kesik, Muharrem. 1071 Malazgirt. İstanbul: Timaş Yayınları 2014. Khoniates, Niketas. Historia (Ioannes ve Manuel Kommenos Devirleri). çev. Fikret Iş1ltan. Ankara: Türk Tarih Kurumu 1995. 
Kinnamos, Ioannes. Hıstorıa (1118 - 1176). yay. haz. Işın Demirkent. Ankara: Türk Tarih Kurumu 2001.

Koca, Salim. "Haçlı Seferleri Sebep ve Sonuçları Bakımından Nasıl Değerlendirilebilir”. Akademik Bakış. 10/20. (2017). 16 -35 .

Kozcaz, Ümit. “Denizli, Antalya ve Isparta Havalisindeki Haçlı Faaliyetleri”. Isparta: Süleyman Demirel Üniversitesi Sosyal Bilimler Enstitüsü Yüksek Lisans Tezi. 2014.

Levtchenko, M, V. Kuruluşundan Yıkılışına Kadar Bizans Tarihi. çev. Maide Selen. İstanbul: Özne Yayınları 2007

Nicola, David. Askeri Tarih Dizisi II. Haçlı Seferi 1148. çev. L. Ece Sakor. İstanbul: Türkiye İş Bankası Yayınları 2014.

Norwich, John Julius. Bizans-3 Gerileme ve Çöküş Dönemi (MS 1082 - 1453). çev. Selen Hırçın Riegel. İstanbul: Kabalcı Yayınları 2013.

Ostrogorsky, Georg. Bizans Devleti Tarihi. çev. Fikret Işıltan. Ankara: Türk Tarih Kurumu 2019.

Rice, Tamara Tilbot. Anadolu Selçuklu Tarihi. çev. Tuna Kaan Taştan. Ankara: Nobel Yayınevi 2015.

Roche, Jason T. "Conrad III and The Second Crusade in The Byzantine Empire and Anatolia, 1147'. Fife: Universty of St. Andrews Doktora Tezi. 2007.

Runciman, Steven. Haçlı Seferleri Tarihi/II. çev. Fikret Işıltan. Ankara: Türk Tarih Kurumu Yayınları 2008.

Sevim Ali. Anadolu'nun Fethi Selçuklular Dönemi. Ankara: Türk Tarih Kurumu Yayınları. 2020.

Smbat, Sparapet. The Chronicle, ed. Robert Bedrosian. New Jersey 2005.

Syrians, Michael. The Chronicle, ed. Robert Bedrosian. Long Branch 2013.

Şakir, Kemal. Tarihi, Coğrafi, İctimai, Sihhi, İktisadi Nokta-i Nazardan Denizli. yay. haz. İbrahim Balık, Denizli: Denizli Büyükşehir Belediyesi Yayınları 2010.

Texier, Charles. Küçük Asya Coğrafyası Tarihi ve Arkeolojisi/II. çev. Ali Suat, Ankara 2002.

Timothy, Gregory E. Bizans Tarihi. çev. Esra Ermen. İstanbul: Yapı Kredi Yayınları 2019.

Turan, Osman. Selçuklular Zamanında Türkiye Tarihi. İstanbul: Nakışlar Yayınevi. 1984.

Tyrensis, Willermus. Haçlı Kroniği III (1143 - 1184). ter. ve notlar Ergin Ayan. İstanbul: Kronik Yayınları 2019. 